Uhrary, New Mexico College of A. \& M. A.

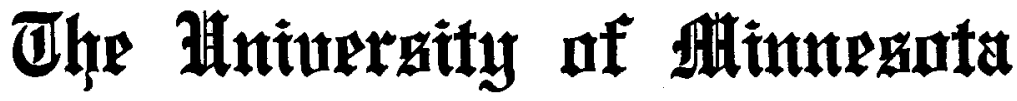

AGRICULTURAL EXPERIMENT STATION

\section{STUDIES ON FUSARIUM DISEASES OF POTATOES AND TRUCK CROPS IN MINNESOTA}

TECHNICAL

G. R. BISBY

DIVISION OF PLANT PATHOLOGY AND BOTANY

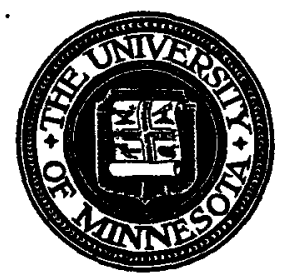




\section{ADMINISTRATIVE OFFICERS}

R. W. Thatcher, M.A., Director

ANDREW Boss, Vice Director

A. D. Wilson, B.S. in Agr., Director of Agricultural Extension and Farmers' Institutes

C. G. Selvig, M.A., Superintendent, Northwest Experiment Station, Crookston

M. J. Thompson, M.S., Superintendent, Northeast Substation, Duluth

O. I. Bergh, B.S.Agr., Superintendent, North Central Substation, Grand Rapids

P. E. Mirler, B.S.A., Superintendent, West Central Substation, Morris

Charles Haralson, Superintendent, Fruit Breeding Farm, Zumbra Heights (P. O. Excelsior)

W. H. Kenety, M.S., Superintendent, Forest Experiment Statiơn, Cloquet

W. P. KIRKWood, B.A., Editor

Alice MCFeELY, Assistant Editor of Bulletins

Harriet W. Sewall, B.A., Librarian

T. J. HoRTon, Photographer

R. M. West, B.S., Secretary

R. A. Gortner, Ph.D., Chief, Division of Agricultural Biochemistry Andrew Boss, Chief, Division of Agronomy and Farm Management C. W. GAY, B.S.A., D.V.M., Chief, Division of Animal Husbandry

Francts Jager, Chief, Division of Bee Culture

C. H. Eckles, M.S., Chief, Division of Dairy Husbandry

*John T. Stewart, Chief, Division of Drainage

W. A. Riley, Ph.D., Chief, Division of Entomology and Economic Zoology

Wirliam Boss, Acting Chief, Division of Farm Engineering

E. G. Cheyney, B.A., Chief, Division of Forestry

W. G. Brierley, M.S. in Hort., Chairman, Division of Horticulture

E. M. Freeman, Ph.D., Chief, Division of Plant Pathology and Botany

A. C. Smith, B.S., Chief, Division of Poultry Husbandry

*W. W. Cumberdand, Ph.D., Chief, Division of Research in Agricultural Economics

F. J. Alway, Ph.D., Chief, Division of Soils

C. P. Fitch, M.S., D.V.M., Chief, Division of Veterinary Medicine

STAFF OF DIVISION OF PLANT PATHOLOGY AND BOTANY

E. M. Freeman, Ph.D., Plant Pathologist and Botanist, Chief

\section{Section of Plant Pathology}

E. C. Stakman, Ph.D., Plant Pathologist, in Charge

G. R. BisBY, Ph.D., Assistant Plant Pathologist

F. Jean Macinnes, B.S., Mycologist

G. R. Hoerner, M.S., Assistant in Plant Pathology.

J. G. Leach, M.S., Assistant in Plant Pathology

A. G. Newhall, B.S., Assistant in Plant Pathology

\section{Section of Seed Laboratory}

R. C. Dahlberg, B.S., Seed Analyst, Acting in Charge

A. H. Larson, B.S., Assistant Seed Analyst

* On leave of absence. 


\section{CONTENTS}

Introduction $\ldots \ldots \ldots \ldots \ldots \ldots \ldots \ldots \ldots \ldots \ldots \ldots \ldots \ldots \ldots \ldots \ldots \ldots \ldots \ldots \ldots \ldots$

Materials and methods ............................ 5

Potato wilt $\ldots \ldots \ldots \ldots \ldots \ldots \ldots \ldots \ldots \ldots \ldots \ldots \ldots \ldots \ldots \ldots \ldots \ldots \ldots \ldots \ldots \ldots$

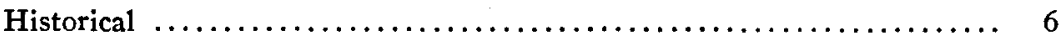

Symptomology of potato wilt conditions in Minnesota .......... 8

Etiology of wilt of potato in Minnesota.................... 10

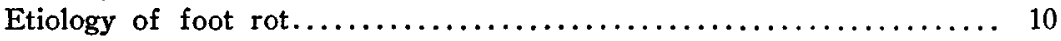

Occurrence of Fusarium oxysporum in potato plants............. 10

Artificial inoculations with $F$. oxysporum on potato plants......... 12

Field studies with seed tubers from wilted plants.............. 13

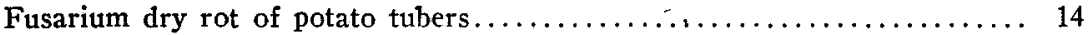

Historical $\ldots \ldots \ldots \ldots \ldots \ldots \ldots \ldots \ldots \ldots \ldots \ldots \ldots \ldots \ldots \ldots \ldots \ldots$

Distribution $\ldots \ldots \ldots \ldots \ldots \ldots \ldots \ldots \ldots \ldots \ldots \ldots \ldots \ldots \ldots \ldots \ldots \ldots \ldots$

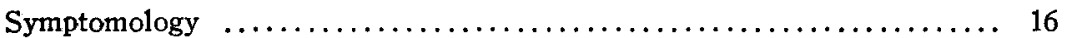

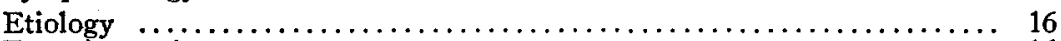

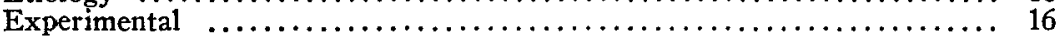

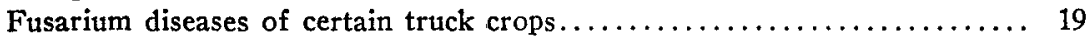

Wilt and root rots of Pisum sativum ......................... 19

Root rots of the bean (Phaseolus vulgaris) ................... 20

Fusarium diseases of other truck crops in Minnesota.............. 20

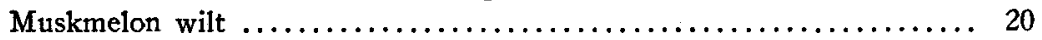

Rots of vegetables.............................. 21

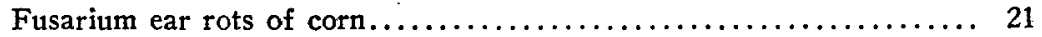

Effect of temperature on various Fusaria . . . . . . . . . . . . . . . . 22

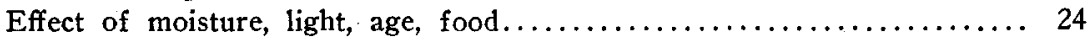

Relations to moisture ............................ 24

Light $\ldots \ldots \ldots \ldots \ldots \ldots \ldots \ldots \ldots \ldots \ldots \ldots \ldots \ldots \ldots \ldots \ldots \ldots \ldots \ldots \ldots \ldots \ldots$

Age $\ldots \ldots \ldots \ldots \ldots \ldots \ldots \ldots \ldots \ldots \ldots \ldots \ldots \ldots \ldots \ldots \ldots \ldots \ldots \ldots \ldots \ldots \ldots \ldots \ldots$

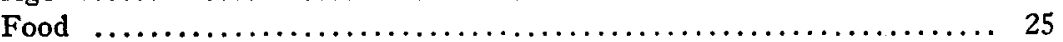

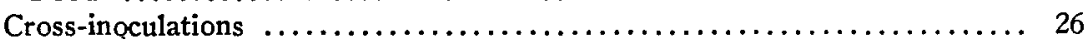

Does the substratum alter the pathogenicity of Fusaria $\ldots \ldots \ldots \ldots \ldots \ldots \ldots$

The production of "toxic substances" by Fusaria................ 28

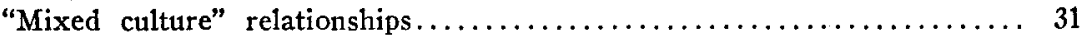

General discussion $\ldots \ldots \ldots \ldots \ldots \ldots \ldots \ldots \ldots \ldots \ldots \ldots \ldots \ldots \ldots \ldots \ldots \ldots \ldots$

Control measures $\ldots \ldots \ldots \ldots \ldots \ldots \ldots \ldots \ldots \ldots \ldots \ldots \ldots \ldots \ldots \ldots \ldots \ldots \ldots \ldots \ldots$

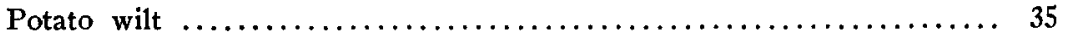

Potato dry rot................................ 37

Summary $\ldots \ldots \ldots \ldots \ldots \ldots \ldots \ldots \ldots \ldots \ldots \ldots \ldots \ldots \ldots \ldots \ldots \ldots \ldots \ldots \ldots \ldots \ldots$

Bibliography $\ldots \ldots \ldots \ldots \ldots \ldots \ldots \ldots \ldots \ldots \ldots \ldots \ldots \ldots \ldots \ldots \ldots \ldots \ldots \ldots \ldots \ldots$

Explanation of plates $\ldots \ldots \ldots \ldots \ldots \ldots \ldots \ldots \ldots \ldots \ldots \ldots \ldots \ldots \ldots \ldots \ldots \ldots$ 


\title{
STUDIES ON FUSARIUM DISEASES OF POTATOES AND TRUCK CROPS IN MINNESOTA
}

\author{
By G. R. BISBy
}

\section{INTRODUCTION}

Fusarium wilt was reported (72) as causing a loss of more than twenty-five million bushels, or 4.54 per cent of the potato crop of the United States in 1917. Despite the large damage due to Phytophthora infestans in this country the same year, the total loss reported from Fusarium wilt was greater. Besides the injury from wilt, Fusarium tuber rots in the field, in storage, and during transportation may destroy from 10 to 50 per cent of the crop $(37,43,72,75)$.

Minnesota is one of the states in which typical Fusarium wilt has been serious. Certain symptoms atypical of wilt have also been under observation for some time, particularly in the Red River Valley. The study of this rather anomalous disease has received particular attention. Fusarium dry rot was also found to present, in Minnesota, certain phases not emphasized heretofore. The writer has also studied certain Fusarium diseases of other truck crops as well as those of the potato.

The genus Fusarium was established by Link in 1809 (34). Various changes in the use of generic and specific names for the fungi in question were made during the succeeding century; the species added were often imperfectly described, and the host or substratum served frequently as the chief distinguishing diagnostic character. Smith and Swingle in 1904 (63) were forced to revert to the oldest available name to designate the Fusarium on potato, viz., $F$. oxysporilm Schlechtendal, 1824. Appel and Wollenweber in 1910 (2) published a monograph of the genus Fusarium, and were able accurately to define several species. The literature to the year 1910 is also summarized. Wollenweber (76), Lewis (32), Sherbakoff (59), and others have also worked intensively on the Fusarium problem and described several new species. The name Fusarium oxysporum is, however, still applied to the fungus commonly causing wilt of potatoes.

\section{MATERIALS AND METHODS}

Isolations were made during the summers of 1916, 1917, and 1918 from potato plants showing various wilt symptoms. The plants were obtained from sections of Minnesota north of St. Paul, particularly 
the Red River Valley region. Several cultures of Fusaria isolated in 1914 and 1915 were furnished by A. G. Tolaas. During the winters, isolations were also made from rotted potato tubers. Isolations were made from garden beans and peas, sweet corn, cucurbits, and tomatoes. Several hundred cultures were studied and numerous inoculations were made in the laboratory, in the greenhouse, and in the field in 1917 and 1918.

Various culture media were used, particularly rice and potato plugs, sweet clover stems, the common agars for dilutions, and $\mathbf{5}$ and 10 per cent dextrose agar for color reactions. The ordinary methods of technique were used unless otherwise stated.

The writer wishes to express his thanks particularly to Dr. E. C. Stakman and Dr. E. M. Freeman, under whom the work was done, for suggestions and supervision. The writer is also indebted to A. G. Tolaas and Dr. W. A. Orton for cultures and other help, and to Dr. C. D. Sherbakoff for tentative corroboration of some determinations. The writer is particularly grateful to Dr. H. A. Edson of the United States Department of Agriculture who in his visits to Minnesota has freely given information and ideas.

The writer has submitted cultures of the various unidentified $\mathrm{Fu}$ saria to Dr. Sherbakoff for such taxonomic disposition as he sees fit.

\section{POTATO WILT}

\section{HISTORICAL}

Smith and Swingle (63) made the first detailed study of the wilt of potato caused by Fusarium oxysporum. The dry rot of tubers discussed by them is now generally considered to be caused chiefly by other species of Fusarium. They described in detail the effects of the wilt fungus on the plant and its entrance into and spread within the tuber. They studied the behavior of the fungus on various media. Control methods for wilt were suggested. While the earlier publication of Stewart (65) on "Another stem blight of potato" deals with a disease similar to wilt, Stewart (66) decided in 1898 that the blight was not communicable and "not caused by any vegetable organism," and recently stated, in letters dated Nov. 18 and 30,1918, "While the symptoms point to Fusarium wilt, I doubt that it was actually that disease." However, "If it is true that tubers showing pronounced discoloration of the fibro-vascular bundles, owing to the infection with Fusarium wilt, do not usually produce affected plants, then there is some reason for believing that my Long Island stem-blight was in reality Fusarium wilt. The tubers which were planted in my experiments were all very definitely affected by the stem-end browning. 
Every piece planted showed the stem-end browning. Accordingly, it seems to me that more diseased plants should have resulted." Clinton's description in 1895 (11) of a "Bundle blackening of tubers" may have been of the ring discoloration caused by $F$. oxysporum. He wrote in a letter dated Dec. 3,1918, "While the tubers mentioned may quite likely have been connected with such a wilt, I have no positive information that they were."

Orton in 1909 (40) reported that the accumulation of $F$. oxysporum and other fungi in the peat soils of sections of California soon made the growing of potatoes unprofitable. Manns (36), as a result of his work, recommended clipping the stem ends of infected tubers. This is now a commonly used control method. Orton in 1914 (42), in comparing wilt due to $F$. oxysporum with leaf roll and other diseases, considered that wilt was "apparently a disease of warmer climates," altho he recognized that "in Minnesota wilt appears to be present in the older communities."

Discussing the occurrence of this disease in Europe, Appel (1, p. 143) states, "The [wilt] disease occurs in Germany also, but is of much less importance." Nicholls (38) reported the presence of $F$. oxysporum in Tasmania, and Carpenter (10) found this fungus in potato vines and tubers in Hawaii. Reports of $F$. oxysporum from other countries are doubtful, since this name has been loosely used.

Jones (27) found potato wilt especially in the older communities in Wisconsin. Milbrath (37) noted its seriousness in North Dakota, and its importance in Minnesota has been recognized for some time by Stakman and Tolaas (64). Kohler (30) may have referred to the stem end browning caused by $F$. oxysporum, tho it may be inferred that dry rot of tubers was also involved in the rot he attributed to "an undetermined species of Fusarium."

Carpenter (8), Link (33), and others have shown that $F$. oxysporum can produce a rot of potatoes. This is not in agreement with Wollenweber's (76) conclusion that members of the Elegans section of the genus Fusarium cause wilt but not rot. F. eumartii Carpenter, belonging to the section Martiella (76, p. 30), has been found by Haskell (20) and C. R. Orton (39) to cause a stem rot and wilt of potato plants, as well as a rot of the tubers. "Potato wilt" may, therefore, be due to more than one species of Fusarium, possibly following certain geographical limits. Orton (42) reported the symptoms of Verticillium wilt to be similar to those of Fusarium wilt and stated that the distribution of the former was restricted more particularly to the northern states. Verticillium wilt is reported (72) to be especially serious in Oregon. Appel (1) has noted (referring presumably particularly to Minnesota) symptoms atypical of the common potato wilt. 
SYMPTOMOLOGY OF POTATO WILT CONDITIONS IN MINNESOTA

The symptoms have been fully described by other writers, and in general agree with those found under Minnesota conditions. Coons (13) recently noted that in Michigan the disease may exhibit two aspects; one, a rapid wilting in which the vine dies when the tubers are about half grown; and another characterized by the dying of the plants "at the close of the growing season." He found these symptoms to depend perhaps on whether the infection is from the seed piece or from the soil.

- Figures 1 and 2 show the wilt symptoms common in Minnesota fields. Except in more severe cases, the plants do not begin to wilt until about blossoming time or later. The symptoms on the upper part of the plants are apparently those resulting from a considerable reduction in water supply. A cross-section of the lower stem reveals the browning of the vascular system and often of the other tissues as well. This browning may extend to the tips of the plants, tho the bundles are often free from hyphae in these upper discolored areas. The roots are usually affected seriously. The tubers, which have ordinarily had an opportunity to develop considerably before the wilting of the plant stops their growth, may be affected at the stem end, as fully described in the literature.

Atypical wilt symptoms such as those mentioned by Appel (1, p. 147) have received particular attention. Other observers had noticed these atypical symptoms, particularly in 1914 and 1915 in the Red River Valley, and had considered that they might be caused by the blackleg organism or some species of Fusarium. For convenience the term "foot rot" will be used to indicate the condition in question. The writer found some of this disease in 1916, practically none in 1917, but in August, 1918, it was found in Polk and Clay counties in the form more characteristic of that seen by Appel, Edson, Stakman, Orton, and others in 1914 and 1915.

Plants affected with foot rot are shown in Figures 3, 4, and 5. There is a dark brown or almost black discoloration of the lower and underground portions of the stem. These discolored areas are often rotted. When secondary organisms are present there may be a typical soft rot. While the symptoms resemble those of blackleg somewhat, there is not the inky black, slimy rot characteristic of blackleg. The disease is, however, confused with blackleg by growers and others.

There is a more abundant development of hyphae in the primary vessels and other tissues of the stem than in stems affected with ordinary wilt. The effect on the roots and stolons is similar to that on portions of the lower stem (see Figure 5). The stem end of the 
tuber may be attacked, and the way paved for invasion by secondary rotting organisms. The above-ground portions of the plant successively wilt, die, and eventually collapse. Fortunately this foot rot occurs more particularly late in the season, as is also ordinarily the case with wilt in Minnesota, so that a considerable crop of tubers may already have been produced. These tubers are, however, liable to suffer considerable injury before or during storage from the invasion of Fusaria and other organisms through the injured point of attachment of the tubers to the affected stolons.

The relation of this foot rot in Clay County, Minnesota, to the weather (United States Weather Record, Moorhead Station) during the 5 years this condition has been under observation is shown in Table I.

TABLE I

Relation of Weather to the Development of Foot Rot

\begin{tabular}{|c|c|c|c|c|c|c|c|c|c|}
\hline \multirow{2}{*}{ Year } & \multicolumn{4}{|c|}{ Precipitation } & \multicolumn{4}{|c|}{ Average temperatire } & \multirow{2}{*}{$\begin{array}{l}\text { Notes on the } \\
\text { disease }\end{array}$} \\
\hline & May & June & July & August & May & June & July & August & \\
\hline & Inches & Inches & Inches & Inches & Degrees & Degrees & Degrees & Degrees & \\
\hline 1914 & 1.47 & 8.92 & 3.65 & 2.89 & 57.4 & 64.8 & 73.1 & 65.0 & Abundant \\
\hline 1915 & 3.93 & 9.13 & 2.22 & 1.05 & 51.7 & 59.2 & 65.2 & 65.2 & Present \\
\hline 1916 & 3.76 & 4.28 & 5.30 & 2.87 & 53.0 & 60.3 & 75.9 & 67.2 & Present \\
\hline 1917 & 0.38 & 1.52 & 0.81 & 0.77 & 53.6 & 61.3 & 75.2 & 66.4 & Absent \\
\hline 1918 & 2.73 & 1.79 & 2.68 & 4.90 & 55.0 & 64.4 & 67.7 & 69.4 & $\begin{array}{l}\text { Present late in } \\
\text { season }\end{array}$ \\
\hline Normal & 2.95 & 4.13 & 3.74 & 3.10 & 54.8 & 64.14 & 68.7 & 65.9 & \\
\hline
\end{tabular}

More than double the normal precipitation occurred in June, in 1914 and 1915. The rainfall was especially heavy in July, 1916. The season of 1917 was very dry, while in 1918 it was dry until late Juiy and early August, when there was considerable precipitation. Moderately high temperature is also undoubtedly a factor in producing Fusarium wilt, altho, as shown by the temperature in July, 1917, the atypical foot rot does not occur as a result of high temperature without abundant rainfall; and as indicated in 1915, these symptoms may appear in a year of high precipitation even with temperatures considerably below normal. Observations indicate further that foot rot attacks the plants seriously only later in the season; even tho weather conditions from planting time on have been favorable to its development. Kohler (30) described Fusarium diseases of potato in Minnesota, and the foot rot condition may have been involved. He stated that "This disease does great havoc in wet years." Poor yields were obtained from planting tubers showing rot. 


\section{ETIOLOGY OF WILT OF POTATO IN MINNESOTA}

The fungi isolated from various parts of wilted plants, particularly the interior of the stem near the surface of the soil, from several regions in Minnesota, especially the Red River Valley, were predominantly Fusaria. Verticillium was obtained in only a very few cases, and then in association with other organisms, indicating that it was only saprophytically or accidentally present. There was no evidence that Verticillium wilt is important in Minnesota. Most frequently the cultures obtained were determinable as Fusarium oxysporum by the character of their conidia, the salmon to lilac color of the medium (potato or rice), the dark bluish green sclerotia, and the buff sporodochia. As was to be expected, contaminations were sometimes present, and other Fusaria than $F$. oxysporum developed occasionally. Sometimes the difficulty in obtaining a "high culture" (Appel and Wollenweber 2, p. 22) of the Fusarium rendered identification somewhat less certain, owing to the paucity of macroconidia produced, or to the suppression of some other distinguishing character. The cultures were, however, run along with authentic $F$. oxysporum obtained originally from Wollenweber's laboratory (Nos. 3315 and 3394) through the courtesy of Dr. W. A. Orton. Specimens were also submitted to Dr. C. D. Sherbakoff for identification.

Ordinary wilt of potato in Minnesota appears, then, to be due, at least predominantly, to Fusarium oxysporum. This fungus has also been isolated several times from tubers showing brown ring discoloration. It was thus obtained from tubers grown as far north as Kittson County, in the extreme northwestern corner of the state.

\section{ETIOLOGY OF FOOT ROT}

Isolations were made from numerous wilted plants showing atypical wilt symptoms in the expectation that organisms other than $F$. oxysporum were the causal agents. Some isolations obtained by A. G. Tolaas from atypically affected plants in 1914 and 1915 were identified by the writer. The fungus obtained from plants showing foot rot symptoms was found in the majority of cases to be $F$. oxysporum and, as already indicated, the unusual appearance is attributed particularly to the heavier precipitation resulting in a watersoaked condition of the soil. This is most likely to occur in a heavy soil such as that in the Red River Valley. Other fungi and several bacteria were also isolated, but all the evidence indicated that they were merely saprophytes.

\section{OCCURRENCE OF FUSARIUM OXYSPORUM IN POTATO PLANTS}

In the course of development of the wilt or foot rot disease, considerable amounts of the infecting fungus are of course accumulated in the tissues of the potato stems, roots, stolons, and even in the tubers. 
The following observations indicate that the fungus may grow on other parts of the plant also, and develop in greater abundance on those parts mentioned.

On vines affected with wilt in the field and placed two or more days in a moist place, a luxuriant growth of fungus may develop. (See Figure 4.) From the surface and the interior of these vines, $F$. oxysporum was isolated. Not infrequently the mycelium and spores of $F$. oxysporum may have developed abundantly in the somewhat hollow areas within the stem of plants affected in the field. Plants affected with wilt or foot rot may thus cause heavy contamination of the soil.

Isolations were made on September 10,1917, to determine if $F$. oxysporum might be present more or less saprophytically in the stems of plants late in the season. This was shortly after a frost had practically destroyed the leaves. These plants had been grown at University Farm, part of them from northern grown seed, had not shown signs of wilt, and had produced a good crop of healthy tubers. Below the surface of the soil the inside of these stems was browned, and from some such stems "high cultures" of $F$. oxysporum were readily obtained. Similar isolations were made later in 1917, and several on October 1 and 2, 1918. The isolations made in 1918 were from the old stems of normal plants which had been killed by frost. They were taken from a field in. Hennepin County which had been sprayed with bordeaux mixture, and which had yielded 214 bushels per acre. $F$. oxysporum was obtained consistently from this material.

The "dry stem rot" of potatoes with which Rhizoctonia is associated is common in Minnesota. That Fusarium oxysporum may occasionally be a factor in causing this condition is indicated by the fact that it was isolated from the external stem lesions of plants affected with "stem rot," as well as from the interior of such stems. The interior of potato stems affected with dry stem rot is often browned, especially near the base. Edson and Shapovalov (15) have shown recently that various fungi, including $F$. oxysporum, may cause stem lesions. Rhizoctonia hyphae may of course be present even if they are not the primary cause of the lesions.

The seed piece under the growing plant is often rotted. If the rot is caused by bacteria it is soft and foul smelling. Species of Fusarium may cause a dry rot. The rot of the seed piece may be soft and without a foul odor. Isolations were made in the season of 1917 from several such cases as the last two. The specimens were obtained from University Farm and other parts of the state. F. oxysporum was often obtained from seed tubers affected with soft rot. From tubers affected with dry rot, $F$. discolor sulphureum (Schl.) App. 
and Wr. and other Fusaria were obtained. Bacteria and other fungi were of course commonly present as secondary organisms. No diffculty was experienced in securing a more or less soft rot of potato tubers with $F$. oxysporum by artificial inoculation.

Considerable mycelium of $F$. oxysporum may occur in and on the leaves of plants growing under moist conditions, even when the lower stem does not show the presence of the fungus. Such leaf infection may presumably result from inoculum carried by insects or spattered by rain. Milbrath (37) reports that leaves may be affected, altho he may have meant only internally. (See also 15.) Cases of external as well as internal infection of leaves and petioles have been secured from artificial infection in the greenhouse.

The relation of $F$. oxysporum to the soil is discussed in another section.

\section{ARTIFICIAL INOCULATIONS WITH F. OXYSPORUM ON POTATO PLANTS}

Many preliminary experiments in the greenhouse and in the field to secure infection and wilt of potato plants by artificially inoculating $F$. oxysporum into the seed piece planted, or into the soil, were unsuccessful. An examination of the literature indicates also that other workers have not had great success in securing infection of potato plants with the wilt organism under ordinary conditions. It is evident that $F$. oxysporum is not vigorously parasitic to actively growing potato plants.

Sometimes such results as shown in Figure 6 were obtained under greenhouse conditions. Rotting of the seed piece, browning of the stem, and death of the leaves ensued from inoculating the seed tuber with $F$. oxysporum. This is hardly characteristic of Fusarium wilt, however, tho resembling the foot rot condition.

In view of the possibility that the average temperature in the greenhouse during the winter months was not sufficiently high for good infection, the cage shown in Figure 7 was constructed, and heated with two carbon electric light bulbs. A soil temperature of from 20 to 30 degrees could thus be maintained. The humidity was of course also high. Figures 8 and 9 show a type of injury resulting from inoculating sterilized soil heavily with $F$. oxysporum under these warm and damp conditions. This injury was caused several times with $F$. oxysporum, and $F$. radicicola Wollenw. caused a similar injury in one trial. Fitch and Bennett (17) illustrate a somewhat similar condition as found in the field. Link (33) also secured stem rots in the laboratory with $F$. oxysporum. Injuries such as are illustrated 
in Figures 8 and 9 are considered entirely comparable with the naturally occurring foot rot condition illustrated in Figures 3 and 4 .

Figures 10 and 11 show two infected plants resulting from a lighter infection of the soil, and are believed to represent a fair greenhouse manifestation of Fusarium wilt. It is to be noted that the upper leaves show the characteristic rolling (see 1, p. 143). The higher temperatures in the warm chamber, while allowing infection, were unfavorable to the potato. Plants placed inside the chamber died sooner than corresponding plants left outside.

\section{FIELD STUDIES WITH SEED TUBERS FROM WILTED PLANTS}

Wilted plants do not result from planting infected seed, unless conditions are favorable to the development of the fungus. These conditions, particularly a high temperature, are often at the same time unfavorable to the potato. Seed from vines wilted in the field, showing more or less of the bundle blackening, usually produced plants in the greenhouse similar to those from normal seed. Such seed planted in the field in 1917 in not seriously infected soil gave no more wilt than several plots from ordinary seed.

A fairly extensive study of the effect of planting tubers produced under wilted vines was made in the field in 1918. Late in the summer of 1917 several Green Mountain potatoes were dug by hand from under badly wilted vines in Clay County, Minnesota. There was no marked amount of stem end discoloration of the tubers at digging time, nor did this vascular browning increase appreciably through the winter. Through the courtesy of Dr. G. H. Coons, a half bushel of tubers was obtained in the spring of 1918 from a field in Michigan which had shown from 30 to 40 per cent of wilt. Plantings were made in the field at University Farm. The tubers from Clay County were planted whole, and those from Michigan were divided into two lots. Several isolations were made from one lot to determine the fungi present in the browned vascular.tissue of the stem end of the tubers. F. oxysporum and various other Fusaria were obtained. The other lot was used for planting, and the tubers were sorted into two groups according to size. The smaller tubers were halved to give eye and stem ends, and the larger tubers were cut longitudinally through the former point of attachment of the stolon, then cut transversely, to give two each of approximately equal eye ends and stem ends. These were planted in two places on University Farm. The stand of the potatoes obtained from Michigan was poor, owing particularly to frost necrosis of the tubers (29) and to the fact that the "seed" had been obtained from seriously affected plants. It was also necessary to plant the tubers rather late in the spring. The seed pieces were planted $16 \mathrm{~T} / 2$ inches apart in rows 3 feet apart. 
The average yield of the tubers from Clay County was slightly more than one pound per hill (29r/2 pounds from 25 hills) or at the rate of 180 bushels per acre. The plants were not wilted. The yield indicates that the seed was not affected; indeed, it is possible that the greater immaturity of such seed resulted in added vigor of the progeny.

The results with the seed from Michigan are summarized in Table II.

TABLE II

Result of Planting Tubers From Badly Wilted Vines

\begin{tabular}{l|c|c|c|c|c}
\hline $\begin{array}{c}\text { Character of } \\
\text { seed piece }\end{array}$ & $\begin{array}{c}\text { Date } \\
\text { planted }\end{array}$ & $\begin{array}{c}\text { Area of } \\
\text { plot* }\end{array}$ & $\begin{array}{c}\text { No. of wilted } \\
\text { plants }\end{array}$ & Yield & $\begin{array}{c}\text { Rate per } \\
\text { acre }\end{array}$ \\
\hline & Sq. Ft. & 0 & Pounds & Bushels \\
Eye quarters & June 4 & 268.5 & 2 & 23.0 & 86.5 \\
Stem quarters & June 4 & 268.5 & 2 & 12.0 & 62.2 \\
Eye haives & June 4 & 148.5 & 1 & 14.5 & 70.9 \\
Stem halves & June 4 & 148.5 & 1 & & \\
\hline
\end{tabular}

* Including proper marginal area about plot.

In 1918 a plot of the eight standard varieties (6) was planted, and a considerable amount of fungus from cultures of $F$. oxysporum introduced into the soil beside each seed piece at planting time. Here again only healthy plants were produced, indicating that none of the varieties is particularly susceptible to the fungus, unless other factors are conducive to the development of wilt:

The data presented in Table II indicate that serious disease does not necessarily follow from planting seed from wilted vines, and that no more wilt may result from the use of the stem ends than from the use of eye ends. Other observations support this view. Wilted plants do not, of course, produce tubers of as good quality as healthy plants, and it can not be denied that infected tubers may introduce more of the disease into the soil. Such seed is considerably less desirable than seed from healthy plants, and plants affected with wilt should be rogued from plots to be dug for seed. Selecting seed or clipping the stem ends is, however, not alone sufficient to avoid loss from wilt. The considerations involved in the use of affected seed from the north for planting in the southern states require further attention.

\section{FUSARIUM DRY ROT OF POTATO TUBERS}

\section{HISTORICAL}

Some of the earlier literature regarding Fusarium rots of potato, both American and European, is summarized by Smith and Swingle (63) and in part by Manns (36), altho these authors did not distinguish between the Fusaria causing dry rot and those causing wilt. 
The monograph by Appel and Wollenweber (2) made it possible to distinguish between species of Fusaria. Jamieson and Wollenweber (25) reported $F$. coeruleum (Lib.) Sacc. and $F$. discolor sulphureum to occur in Germany as wound parasites, and the American F. trichothecioides Wollenw. was described and reported from Washington, Minnesota, Iowa, Nebraska, and South Dakota. Inoculation studies were described. F. tuberivorum Wilcox and Link (75) was considered a synonym of the previously established $F$. trichothecioides. Orton (41) in 1913 gave a brief description of this "powdery dry rot" and suggested methods of control. Wollenweber (76) distinguished sharply between wilt- and rot-producing Fusaria. Carpenter (8), besides showing that this sharp distinction did not hold for tuber rots, described $F$. eumartii as a new species of Fusarium causing dry and wet rot of tubers. He also reported $F$. radicicola as producing tuber rot through wound infection. Pratt $(49,51,52)$ showed that $F$. radicicola and $F$. trichothecioides were apparently well distributed through the western desert soils, and suggested disinfecting the stock before storage or the use of cold storage, as a control measure against rot. Link (33) has shown that $F$. trichothecioides can cause wilt as well as rot, and also that $F$. oxysporum can cause rot as well as wilt. Sherbakoff (59) stated that the Fusarium most commonly producing potato rot in the eastern United States is $F$. coeruleum. Pethybridge $(46,47,48)$, in Ireland, performed experiments with dry rot of potatoes which he considered due to $F$. coeruleum. Orton (39) and Haskell (20) have found that $F$. eumartii can cause, besides a tuber rot, a wilt or stem rot of the potato plant. Milbrath (37) reported dry rot to be serious in North Dakota, causing a loss of "over 20 per cent in all storehouses in the Northwest" in 1914. Altho he did not specify which Fusarium was responsible, it is noteworthy that Carpenter mentions having isolated $F$. discolor sulphureum from tubers sent in by Milbrath, as well as from tubers obtained from South Dakota. Other references to $F$. discolor sulphureum $(2,25,59,76)$ mention its presence in Germany, and nowhere has the writer seen it referred to as being serious in the United States.

\section{DISTRIBUTION}

In the United States, Fusarium dry rots appear to be widely distributed east and west, but the north central part of the country has not been very critically surveyed. In Minnesota, isolations have been made from tubers grown in Kittson, Pennington, Polk, Norman, Mahnomen, Clay, Wilkin, Otter Tail, Bigstone, Swift, and Lincoln counties, along the western side of Minnesota, and from Brookings County, 
South Dakota. Some have also been made from the region of the Twin Cities and from Crow Wing and Kanabec counties.

\section{SYMPTOMOLOGY}

The Fusarium dry rot of potatoes found in Minnesota is a brown, compact, firm rot, without the foul odor of bacterial rots. Cavities are often present in the tissues. These cavities and the tissues contain considerable mycelium which develops readily and abundantly when the tuber is placed in a damp chamber. From the edges of the rotted areas, pure cultures of the fungus may usually be obtained directly from tissue cultures. The skin of the potato is often wrinkled. Figures 12,13, and 14 show the appearance of this rot as found in storage. The rot starts at any point on the potato, and in the case of stored potatoes usually from a wound. It is more abundant as the winter advances. It does not have the powdery appearance characteristic of the rot caused by $F$. trichothecioides, because the spore masses when present are more compact and less dry.

Sections of rotted potato show that the fungus grows through the cells in considerable abundance. The observation of Orton (39) and Pratt (49) that a dry rot fungus has a tendency to follow the vascular system can be confirmed in tubers rotted by $F$. discolor sulphureum. The writer's experience in general corroborates Carpenter's observations (8) that there is no real distinction between the effects of Fusaria causing dry and soft rots, altho $F$. discolor sulphureum under ordinary conditions produces a dry rot.

\section{ETIOLOGY}

F. discolor sulphureum was obtained readily from affected tubers grown in many parts of Minnesota. Altho the fact that this Fusarium is the cause of a dry rot of potatoes has not been emphasized, it is one of the most common causes of rot in Minnesota, particularly in the Red River Valley. The ability of this fungus to cause dry rot has been demonstrated frequently.

\section{EXPERIMENTAL}

Efforts to determine varietal differences in susceptibility were unsuccessful. The eight standard varieties for Minnesota (Brown and Wellington, 6) were used, and rot developed from wound inoculations in each variety.

A series of experiments was made to determine the relations of injury to the tuber and of moisture and temperature to the development of the rot caused by $F$. discolor sulphureum. Tubers were inoculated on the uninjured epidermis, on the surface after slight wounding with 
a sterile scalpel, and in deeper cuts into the tuber. Sets of inoculated tubers were kept at different temperatures under damp conditions, and similar sets in dessicators containing calcium chloride. The results are summarized in Table III. (See Figure 15.) The extent and rapidity of the rot is proportional to the seriousness of the injury to the tuber, tho the fungus may sometimes enter through uninjured surfaces, probably through lenticels. The later series of inoculations (December, 1918), incubated for 13 days (see Table III), resulted in less infection than in the previous experiments. A less vigorous "strain" of the Fusarium may have been used. There are characteristic differences in the rot developed at different temperatures. Under cooler conditions, the tissues are darkened and contain few "pockets" and few spores. It is evident that the fungus can rot tubers readily under dry conditions, especially if it gains entrance through wounds. The absence of wounds appears to retard the development of $F$. discolor sulphureum more than dryness or storage temperature, except in the case of cold storage.

TABLE III

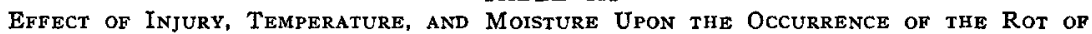
POTATOES CAUSED BY $F$. discolor sulphureum

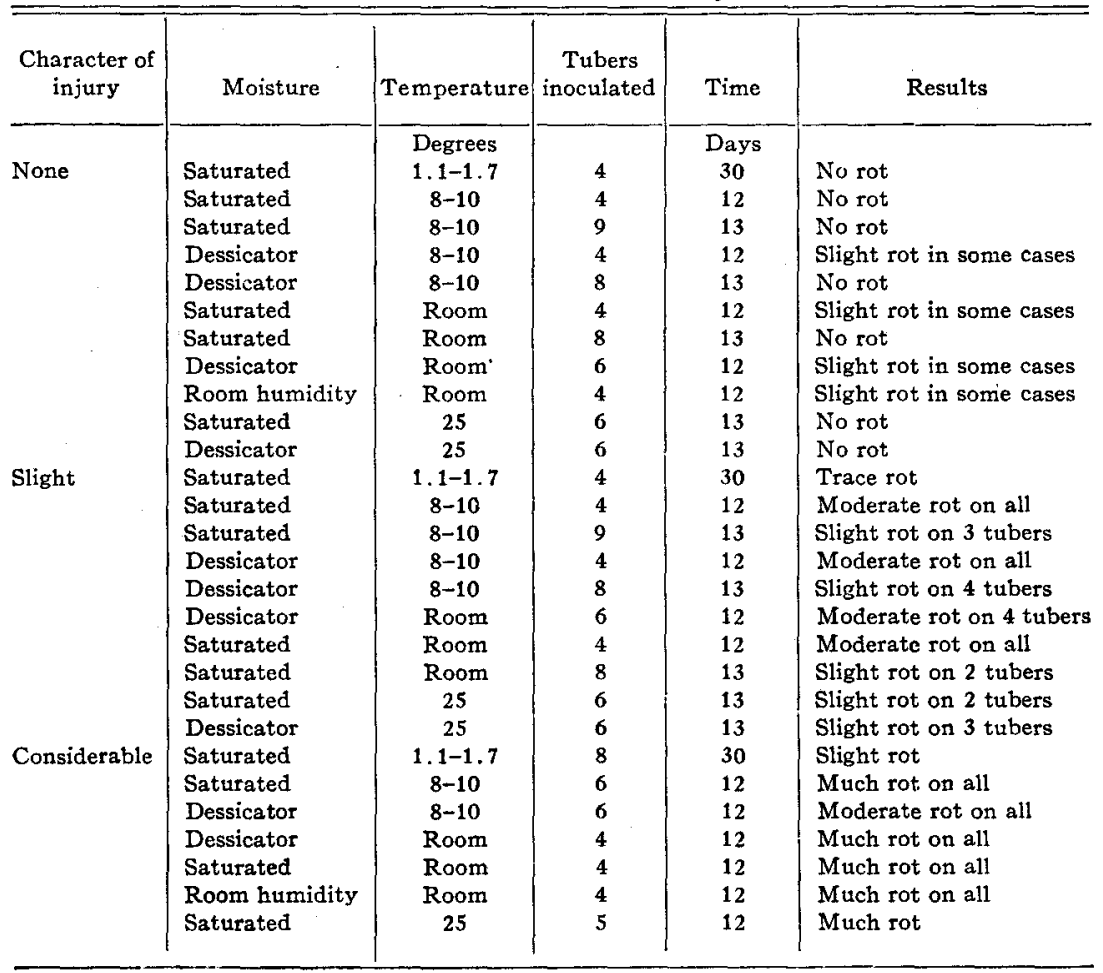


Pethybridge (47) has reported that young sprouts of uninjured tubers may be killed by heavy inoculations with $F$. coeruleum. $F$. discolor sulphureum likewise injures young sprouts if present in abundance.

Sherbakoff (59) and Pethybridge (47) have found that potato tubers rot more readily after sprouting. To determine the relative susceptibility to rot of old and new potatoes, several inoculations were made October 16,1917, on recently harvested tubers and on tubers of the 1916 crop kept in cold storage for more than a year. The latter had sprouts only about fifteen millimeters long at the beginning of the experiment. At room temperature under a bell jar, the tubers grown in 1916 showed, October 26, about twice as large an area of rot as did those of the 1917 crop. The difference was due partly to greater shrinkage of tissue in the older potatoes. Nevertheless the newer potatoes had developed a considerable amount of rot. Additional tests with sprouted and non-sprouted tubers grown the same year indicated that while sprouted tubers usually rotted more extensively, sprouting was not at all a controlling factor in the development of the rot. In sprouted tubers there is a marked shrinkage of the tissue. Naturally infected tubers frequently rotted before the appearance of any sprouts.

Experiments to determine the effect of the fungus on tubers showing frost necrosis (Jones and Bailey, 29) as compared with healthy tubers, were made by inoculating, at the same time, both kinds of tubers. These experiments failed to show that the injury by frost had increased susceptibility to rot. Likewise, it was found that the tubers from "constitutionally degenerate" plants which had shown the socalled curly dwarf symptoms were no more susceptible to the rot caused by $F$. discolor sulphureum than were normal tubers. Indeed, the degenerate tubers often showed smaller rotted areas than did the healthy tubers.

No characteristic wilting of the foliage resulted on potato plants grown from tubers infected with $F$. discolor sulphureum. Several trials for the purpose of determining the effect of planting diseased tubers under field and greenhouse conditions gave the following results:

1. If the tuber or seed piece were badly affected at planting time, the continued rotting frequently resulted in the destruction of the sprout. Sometimes this destruction of the seed piece and the sprout ensued even when only a small amount of rot was present at planting time.

2. If the sprout were well started before the seed piece was completely rotted, it usually continued to grow, altho the resulting plant was unthrifty, owing to the loss of the reserve food in the seed piece, 
and also perhaps in part to the presence of "toxic substances" (see below) in the rotting tissue in contact with the base of the sprout.

3. The rot might not develop rapidly enough to affect the sprout or growing plant. (Figures 16, 17, and 18 show examples of cases 2 and 3.)

Fusarium trichothecioides Wollenw. has been reported from St. Paul $(25,8)$. The writer is uncertain as to whether the tubers referred to were grown in St. Paul or collected there. At any rate, he has never isolated $F$. trichothecioides from a potato grown in Minnesota. This, of course, does not mean that it does not occur, since the whole state has not as yet been thoroly surveyed for tuber rots, but this Fusarium is apparently not abundant. It has been isolated several times from potatoes shipped in from western points, including one lot from North Dakota.

\section{FUSARIUM DISEASES OF CERTAIN TRUCK CROPS}

Fusarium injuries may be of considerable importance to various truck crops in the United States (71), even tho a definite wilt is not produced. Root rots and stem injuries due to Fusaria are rather common on several crops. Members of the Leguminosae (see 60) such as cowpea, pigeon pea, and soybean, are seriously affected.

\section{WILT AND ROOT ROTS OF PISUM SATIVUM}

Fusarium vasinfectum pisi was established by Van Hall (73) as the cause of St. John's disease of the garden pea. The Fusarium which Schikorra (60) assigned to the same species was determined by Appel and Wollenweber (2) to be identical with their species $F$. falcatum, which was reported to occur on garden peas in Germany, and on tomato fruit in Germany and the United States $(76,59)$. Lewis (32) isolated a Fusarium from diseased Pisum sativum in Maine, which Wollenweber determined as $F$. orthoceras App. and Wr. Wollenweber (76) also described a new species, $F$. redolens, with the following notes: "Vascular parasite, cause of wilt and foot disease of Pisum sativum. Distribution unknown." This author also considered that "More than one species, differing both in size of conidia and color of conidial masses, may cause the St. John's disease of the garden pea."

Little information is as yet at hand regarding the distribution or seriousness of Fusaria affecting the garden pea in the United States.

The first report of a serious outbreak of this disease in Minnesota came in late June, 1916, from Le Sueur. The disease caused considerable damage in a field of about 16 acres. A wilt of garden peas was reported from near Kasson in 1917. 
Species of Fusarium have been found (4) associated with the diseased condition of roots and stems of the garden pea in Minnesota. One species, evidently belonging taxonomically in the section Martiella Wollenw. (76) has been found to be particularly pathogenic. The stem and root injuries resulting in wilt of the pea plants have been obtained from infecting the soil or sterilized seeds when planted in either sterilized or unsterilized soil. If considerable inoculum be applied, the seeds may rot before sprouting or shortly after (Figure 19). With a less heavy infection the plants may grow to a considerable size before the general rotting of the roots and lower stem results in wilting and death.

Studies of this disease are being made by Dr. F. R. Jones, of the United States Department of Agriculture, with whom the writer is coöperating. Cultures of the Fusarium have been submitted to Dr. Sherbakoff for taxonomic consideration. The writer has used this Fusarium in some comparative studies with other Fusaria, as reported later in this paper.

\section{ROOT ROTS OF THE BEAN (PHASEOLUS VULGARIS)}

Burkholder (7) reported Fusarium root rots of the bean to be serious in New York State. Reddick (55) reported that Burkholder found the fungus to be similar morphologically to $F$. martii, but different physiologically; he called the fungus Fusarium martii phaseoli, and described experiments indicating important relations between temperature and the development of bean plants and the "hemi parasite." Several pathologists have reported $(71$, p. 8$)$ troubles from root rots due probably to Fusarium, from various sections of the United States.

Rots of the roots and lower stem of bean plants have been noted in Minnesota, particularly in the spring while the plants are still small and the ground cool. From such injured roots a Fusarium was isolated. Inoculation experiments demonstrated the pathogenicity of this fungus to bean plants. This Fusarium has been utilized in some temperature studies, as noted under a subsequent heading. Upon submission of the fungus to Dr. Burkholder, he pronounced it to be probably different from his $F$. martii phaseoli.

\section{FUSARIUM DISEASES OF OTHER TRUCK CROPS IN MINNESOTA}

Muskmelon wilt.-A Fusarium was isolated by G. R. Hoerner, of the Section of Plant Pathology, in 1916, from wilted muskmelon vines. The fungus has not been found to agree with either $F$. niveum $\mathrm{E}$. F. Smith or $F$. vasinfectum Atk. (see 61, 71, 72). Inoculation experiments did not demonstrate that it was particularly parasitic to muskmelons or cucumbers. In 1918, two reports of non-bacterial wilt were 
received from the region of the Twin Cities, and from one field Fusaria somewhat similar to the one isolated in 1916 were obtained. The trouble did not become serious in the field in 1918, and the writer considers the Fusaria to have been present semi-parasitically, gaining entrance when the plants were in a nonvigorous condition.

Rots of vegetables.-Fusaria causing rots of cucumber fruits have been isolated, and are not uncommon, affecting either green or ripe cucumbers. In view of the inoculation experiments reported later, the writer regards these Fusaria as acting semi-parasitically, not as specific parasites restricted to the cucumber. Lewis (32) obtained rots of cucumber fruits with several different Fusaria.

Wollenweber (76) has described Fusarium sclerotium as causing a rot of tomato fruits, and has found that $F$. falcatum also causes a rot of tomatoes. He named a fungus obtained by Lewis (32) from tomato fruits, $F$. citrinum. The writer also has isolated Fusaria from the tomato fruit. A wilt of tomato such as is caused by $F$. lycopersici Sacc. in the south and F. oxysporum and $F$. orthoceras App. and Wr. in the west (24) has not been definitely found in Minnesota.

Rots of carrot and other vegetables due to various Fusaria are quite common, particularly in storage and following wounds. The rots may be soft or dry. No specificity appears to exist between these fungi causing various fruit and vegetable rots and the hosts on which they may be found. This is also indicated by the inoculation experiments recorded later.

Fusarium ear rots of corn (Zea mays).-Pammel, King, and Seal (44) have summarized the literature of Fusarium diseases of corn. They found that roots, stalks, and ears were attacked, but the Fusaria isolated were not named. Sheldon (58) described Fusarium moniliforme as the cause of moldy corn. Hoffer and Holbert (22) have recently called attention to injury to corn plants by Fusaria and bacteria.

The symptoms considered by the writer have been particularly rots of the ear and cob, ordinarily pinkish or reddish in color. Such rots were widely distributed in Minnesota in 1917. As a result of early frosts that year, much immature corn was gathered.

Fusaria were isolated from field corn in the crib, but more particularly from sweet corn in the field. While inoculations have not been made to determine the pathogenicity, it was soon suggested from laboratory studies in 1917 that the Fusarium from some isolations from corn (both sweet and field varieties) were identical morphologically with F. culmorum (W. Sm.) Sacc., the wheat scab organism. Hoffer has been working upon this problem, and with others has published (23) results of cross-inoculations. 


\section{EFFECT OF TEMPERATURE ON VARIOUS FUSARIA}

The relations of temperatures affecting the development of host and parasite are highly important. Considering Fusaria, the work of Humphrey (24), Link (33), Tisdale (69), Gilman (18), and others is summarized by Jones (28). The papers of Reddick (55) and of Wollenweber (76) also deal with this question.

Several of these authors have emphasized the fact that infection by the Fusarium is more serious at, or even dependent upon, a temperature near the optimum for the fungus; in the case of flax wilt, there appears to be a definite temperature below which the plant is not affected (Tisdale, 1.c.). The suggestion of Reddick (1.c.) that the fungus may develop upon the host when unfavorable temperature has lowered its vitality, is important and has perhaps been partially overlooked.

Several experiments were begun in 1917 to test the relation of certain Fusaria to temperature. While the relation of the host plants to the different temperatures was not critically determined, considerable is already known in a general way.

The low temperature used in the experiment (1.1 to 1.7 degrees C.) was practically constant. The temperatures of 25,30 , and 35 degrees were fairly constant. The medium used of course strongly affects the rate of growth of the fungus. In these experiments, potato dextrose agar was employed, and since the four Fusaria were subjected in each case to the same conditions, the data are comparable at each of the different temperatures. More than one set of cultures was run at most temperatures, and from three to eight measurements were made at different periods of time. A partial series run later and not included in the table gave figures somewhat different, tho a similar relation existed between the rates of growth of the four Fusaria at each of the temperatures utilized.

Analysis of Table IV shows that the Fusarium from the bean can make a good growth at 1.1 to 1.7 degrees C., and at temperatures of 20 degrees and below grows somewhat more rapidly than does the Fusarium from pea, while at 25 degrees and above the reverse is true. The growth of each Fusarium is comparatively more favorable at the temperature more unfavorable for its host. This supplements Reddick's (55) observations. $F$. oxysporum grows well at temperatures unfavorable for the potato plant. $F$. discolor sulphureum makes but slight growth at 1.1 to 1.7 degrees, but is able to cause a slight amount of rot at this temperature (see Figure 20). At 8 to 10 degrees, this fungus rots tubers readily as shown in Figure 21 . 
TABLE IV

The EfFect of Temperature on the Rate and Character of Growth of Fusaria

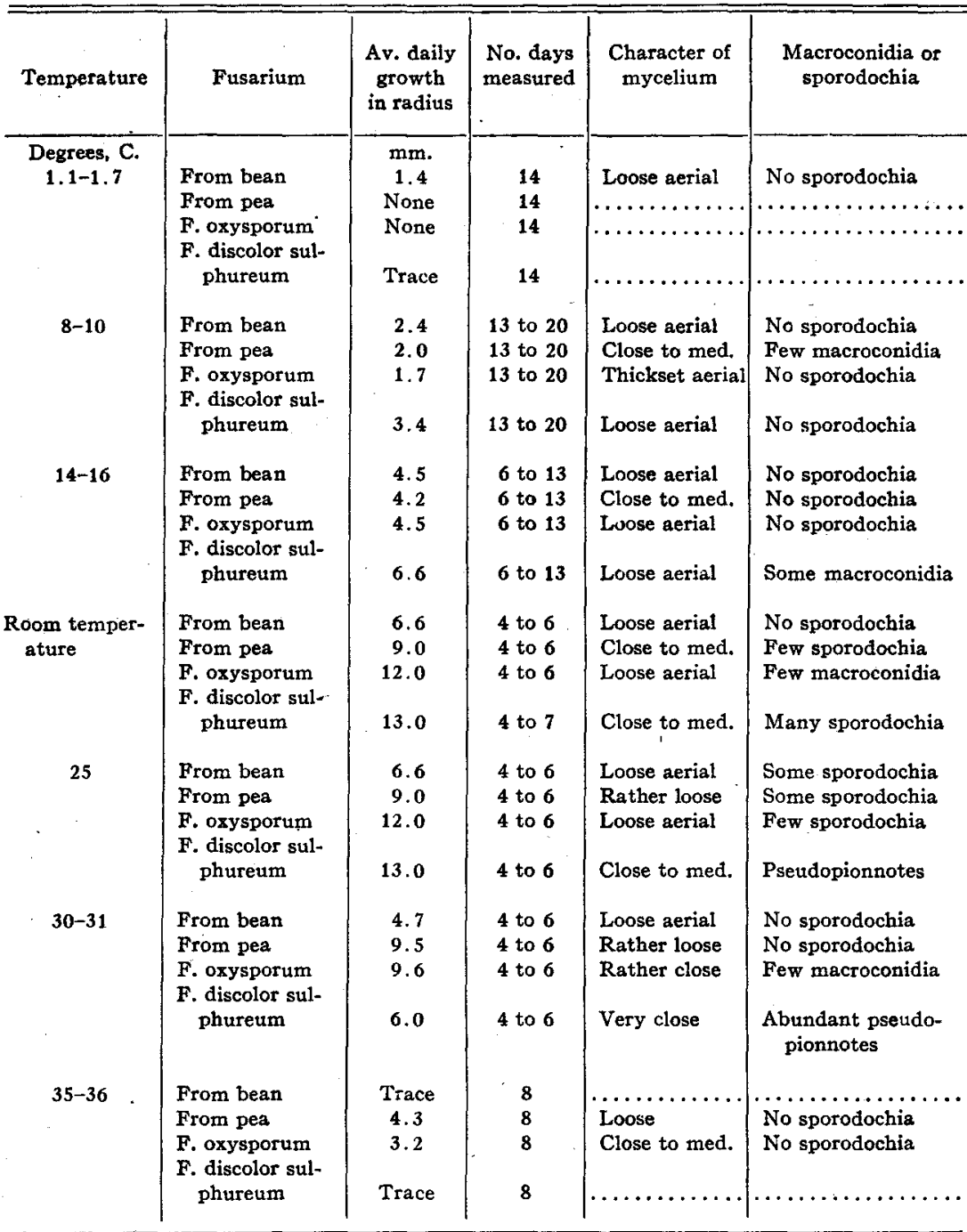

From about 8 to 15 degrees $C ., F$. discolor sulphureum develops a loose vegetative mass of mycelium without sporodochia, whereas at about 20 degrees and above macroconidia are produced, more abundantly as the temperature rises, until at 30 degrees a dense pseudopionnotes is produced, with mycelium close to or sunken in the agar. Removal of cultures of this fungus from higher or lower temperatures to room temperature allows again the development of the growth characteristic in the new temperature. (Figurés-22 and 27.) The abundant spore production of this fungus at higher temperatures has a bearing 
on the accumulation of inoculum in storage houses, and perhaps fields, during the summer months.

Freezing would hardly be expected to injure Fusaria. Bartram (3) reported, however, that a Fusarium obtained from conifers succumbed to temperatures occurring in winter at Burlington, Vermont. Cultures of $F$. oxysporum exposed to the outside temperature from December 21, 1917, to February 11, 1918, began growing again when brought indoors, and transfers developed normally. This exposure not only involved at times temperatures far below freezing, but, since the cultures were placed on the south side of the building, exposure to the sun and to alternate freezing and thawing.

Similarly, cultures of $F$. discolor sulphureum were uninjured after exposure out of doors for more than a month during the winter. Wilcox, Link, and Pool (75) found that freezing did not injure $F$. trichothecioides. The frequent observation that Fusaria, and various other fungi as well, can overwinter in the soil shows quite clearly that low temperatures exert no serious deleterious effect upon them.

\section{EFFECT OF MOISTURE, LIGHT, AGE, FOOD}

Relations to moisture.-Fusaria grow readily in culture both on rather dry substances such as clover stems, and when submerged in liquid media. Possible oxygen relations involved have not been tested by the writer. That these fungi withstand dry conditions well is indicated by the fact that more than a year after inoculation test tube agar cultures of $F$. oxysporum were still viable; $F$. trichothecioides was still viable after 25 months. The tubes were exposed all this time to the dry and often warm conditions of the laboratory. Humphrey $(24$, p. 15$)$ reports viability of cultures containing chlamydospores after two years' laboratory dessication in a test tube.

Light.-Cultures grow almost equally well in light or dark, altho, as frequently observed, the colors produced are much more vivid in rather bright light; sunlight on the other hand, is unfavorable.

Age.-That cultures of Fusaria may lose their virulence after some period of time on culture media is suggested as a possibility by Sherbakoff (59) and Link (33). The writer has not found that this necessarily holds true. Cultures of $F$. oxysporum obtained as mentioned from Wollenweber's laboratory on February 8, 1915, and which had of course been isolated some time previously, were still able to cause infection of potato stems and rot of tubers about three years later. Appel and Wollenweber (2) note that cultures were still virulent after two years; Edson and Shapovalov (15) found that age did not lessen pathogenicity. It is of course true that cultures may cease to be "high cultures" and produce fewer macroconidia if transferred, 
for example, only at long periods. While such cultures may not be as actively virulent as "high cultures," a ready way sometimes to bring about a high culture is by inoculation into the proper host and by subsequent reisolation.

Food.-While the writer has not endeavored to determine specifically which enzymes are produced by certain species of Fusarium, he has grown these fungi on various media, both synthetic and complex; it is obvious that they are not restricted in their saprophytic development as to the food used. The work of Hawkins (21) showed that sucrase, maltase, xylanase, and diastase were secreted by both $F$. oxysporum and $F$. radicicola. He found these two fungi to have practically the same effect on the potato.

The situation with regard to the use of starch by various Fusaria requires special consideration. Smith and Swingle (63) noted that the starch grains in a rotted potato (causative Fusarium not certainly $F$. oxysporum) were not corroded, altho they found some change as evidenced by the staining reaction with iodine. Hawkins (1.c.) observed that starch was not used by the Fusaria with which he worked unless first gelatinized. Hawkins sought an explanation in the slowness of action or diffusibility of the enzyme. It may be noted, however, that many writers consider the outer layer of the starch grain to be not homogeneous with the interior. Shapovalov (56) translates Naumov and Pomasski as finding, however, that $F$. roseum Link and F. subulatum App. and Wr., which caused "intoxicating bread," dissolved starch in the seeds of cereals.

The writer has investigated the effect of $F$. discolor sulphureum on starch, with results similar to those reported by Hawkins: starch grains in a rotted potato are intact, and stain as darkly with stronger iodine solutions as grains from normal potatoes. The appearance of less blue (more purplish or reddish) staining with dilute iodine is sometimes to be noted with starch from such rotted potatoes, and is of uncertain significance. On gelatinized starch, that is, starch paste made by boiling starch with distilled water, $F$. discolor sulphureum and several other species of Fusarium grew fairly well and produced normal spores. It would seem, however, that, barring a possibly less ready separation from the tissue, commercial starch should be procurable from dry rotted potatoes.

To test the effect of prolonged action of fungi and bacteria causing rot of potato tubers, a number of tubers seriously affected with $F$. discolor sulphureum were placed on March 1, 1918, in a jar, and this was covered and set away to allow the continued action of the Fusarium as well as any other organisms present. From time to time 
samples were removed for examination of the starch grains, the mass being then stirred and set aside. The last examination was made December 24, 1918, at which time, after nearly 10 months of "rotting," the mass still contained entirely normal starch grains. Whether the number was reduced can not be stated, but no grains were found showing partial erosion. The rotting of potato tubers does not necessarily affect the starch present. Edson (15a) has recently published in some detail on this point.

\section{CROSS-INOCULATIONS}

Table $\mathrm{V}$ shows the results of some of the cross-inoculations attempted. The data are not presented unless the lesions produced were fairly definite. The rots reported were all obtained at room temperature. The plants inoculated were kept at a greenhouse temperature of about 18 to 24 degrees $C$.

The evidence presented in Table $\mathrm{V}$ seems to indicate that various Fusaria may cause rot on certain fruits, such as cucumber, apple, or tomato, the host serving as hardly more than a "culture medium," in these cases, for the development of the Fusarium. Potato tubers may also be rotted by several species of Fusarium, altho it was found that with certain Fusaria, rot was obtained more readily after the potatoes had been dug some little time. Sprouting did not seem to be a necessary corollary. Such forms as $F$. trichothecioides and $F$. discolor sulphureum, could of course produce rot at any time. While it is evident that certain forms, including those just noted, are, under nat. ural conditions, the chief producers of injury to potatoes, it is not apparent that any certain species of Fusarium causes rot on tomato, cucumber, and other vegetables.

Cross-inoculation experiments are being continued, since it is evident that the effect of Fusaria on different hosts is important from the standpoint of crop rotation. 
TABLE $V$

Results of Cross Inoculations with Fusaria

\begin{tabular}{|c|c|c|c|c|}
\hline Fusarium & Host tried & Development & $\begin{array}{l}\text { Extent of } \\
\text { injury } 3 \text { or } 4 \\
\text { weeks }\end{array}$ & Remarks \\
\hline F. oxysporum & $\begin{array}{l}\text { Orange fruit } \\
\text { Tomato fruit } \\
\text { Potato tuber } \\
\text { Potato plants } \\
\text { Cucumber fruits } \\
\text { Apple Fruit } \\
\text { Bean plants } \\
\text { Pea plants }\end{array}$ & $\begin{array}{l}\text { Rot } \\
\text { Rot } \\
\text { Rot } \\
\text { Injury } \\
\text { Soft rot } \\
\text { Rot } \\
\text { Noeffect noted } \\
\text { Slight root in- } \\
\quad \text { jury }\end{array}$ & $\begin{array}{l}1 / 4 \text { fruit } \\
1 / 2 \text { fruit } \\
\text { Whole tuber } \\
\ldots \ldots \ldots \ldots \ldots \\
\ldots \ldots \ldots \ldots \ldots \\
1 / 3 \text { fruit } \\
\ldots \ldots \ldots \ldots \ldots\end{array}$ & $\begin{array}{l}\text { Usually a soft rot. } \\
\text { See previous data } \\
\text { Sterilized soil used }\end{array}$ \\
\hline F. discolor sulphureum & $\begin{array}{l}\text { Cucumber fruits } \\
\text { Bean plants } \\
\text { Pea plants } \\
\text { Potato plants } \\
\text { Potato tuber }\end{array}$ & $\begin{array}{l}\text { Soft rot } \\
\text { No wilt or rot } \\
\text { noted } \\
\text { No wilt or rot } \\
\text { noted } \\
\text { No "wilt" } \\
\text { Rot, usually } \\
\text { dry rot }\end{array}$ & $\begin{array}{l}\ldots \ldots \ldots \ldots \\
\text { Whole tuber }\end{array}$ & $\begin{array}{l}\text { Abundant rot } \\
\text { Light and heavy in- } \\
\text { oculations made } \\
\text { Light and heavy in- } \\
\text { oculations made } \\
\text { See previous data } \\
\text { See previous data }\end{array}$ \\
\hline F. trichothecioides & $\begin{array}{l}\text { Orange fruit } \\
\text { Lemon fruit } \\
\text { Apple fruit } \\
\text { Sweet potato } \\
\text { Cucumber fruit } \\
\text { Tomato fruit } \\
\text { Carrot } \\
\text { Year old pota- } \\
\text { to tuber } \\
\text { Newly dug po- } \\
\text { tato } \\
\text { Rotted potato } \\
\text { tubers plant- } \\
\text { ed }\end{array}$ & $\begin{array}{l}\text { Rather soft rot } \\
\text { Rather soft rot } \\
\text { Rather soft rot } \\
\text { Slight rot } \\
\text { Soft rot } \\
\text { Soft rot } \\
\text { Dry rot } \\
\text { Dry rot } \\
\text { Dry rot }\end{array}$ & $\begin{array}{l}1 / 3 \text { fruit } \\
1 / 4 \text { fruit } \\
1 / 2 \text { fruit } \\
25 \mathrm{~mm} \\
1 / 2 \text { fruit } \\
1 / 2 \text { fruit } \\
3 / 4 \text { carrot } \\
1 / 2 \text { tuber } \\
1 / 4 \text { tuber }\end{array}$ & $\begin{array}{l}\text { Rind and core par- } \\
\text { ticularly attacked }\end{array}$ \\
\hline F. culmorum & $\begin{array}{l}\text { Apple fruit } \\
\text { Potato tuber } \\
\text { Cucumber fruit } \\
\text { Bean plants } \\
\text { Pea plants }\end{array}$ & $\begin{array}{l}\text { Slight rot } \\
\text { Rather soft rot } \\
\text { Soft rot } \\
\text { No injury not-- } \\
\text { ed } \\
\text { No injury not- } \\
\text { ed }\end{array}$ & $\begin{array}{l}30 \mathrm{~mm} \\
\ldots \ldots \ldots \ldots \ldots \\
1 / 4 \text { fruit } \\
\ldots \ldots \ldots \ldots \ldots\end{array}$ & $\begin{array}{l}\text { See previous data and } \\
\text { Fig. } 21\end{array}$ \\
\hline Fusarium from bean & $\begin{array}{l}\text { Putato tuber } \\
\text { Bean plant } \\
\text { Pea plant }\end{array}$ & $\begin{array}{l}\text { Rot in some } \\
\quad \text { cases } \\
\text { Root rots } \\
\text { Slight root in- } \\
\text { jury }\end{array}$ & $\begin{array}{l}25-40 \mathrm{~mm} \\
\ldots \ldots \ldots \ldots \ldots\end{array}$ & See previous data \\
\hline $\begin{array}{l}\text { F. lini } \\
\text { F. Iycopersici }\end{array}$ & $\begin{array}{l}\text { Potato tuber } \\
\text { Pea plant } \\
\text { Bean plant } \\
\text { Potato tuber } \\
\text { Cucumber fruit } \\
\text { Cucumber fruit }\end{array}$ & $\begin{array}{l}\text { Rot in some } \\
\quad \text { cases } \\
\text { Root rots and } \\
\quad \text { wilt } \\
\text { Trace root in- } \\
\quad \text { jury } \\
\text { Some rot } \\
\text { Rot } \\
\text { Rot }\end{array}$ & $\begin{array}{l}20-40 \mathrm{~mm} \\
1 / 4 \text { fruit } \\
1 / 4 \text { fruit }\end{array}$ & Injury occasional \\
\hline
\end{tabular}




\section{DOES THE SUBSTRATUM ALTER THE PATHOGENICITY OF FUSARIA?}

Carpenter (8) has reported several Fusaria as able to produce rot in potatoes. Sherbakoff $(59$, p. 100) noted that "Several series of inoculations of potato tubers showed (a) that a considerable number of Fusaria can cause more or less rapid decay of the tubers, and (b) that most of the Fusaria readily produce rot only after the tubers begin to sprout." Wollenweber $(76$, p. 37) considered that in general the wilt parasite of one host was not found on living organs of another host, and that "the possibility of the adaptation of the parasite decreases proportionately to the taxonomic distance of the host." $\mathrm{He}$ states, however, that "whether such [gradual to other hosts] adaptation occurs and causes changes in the nature of the parasite, indicated in pure culture by differences in general appearance, production of color, etc., has not been determined." Sherbakoff (1. c. p. 103) noted cases of possible mutations or fluctuations and of temporary changes in morphological characters.

Sherbakoff also reported that he had isolated $F$. culmorum from rotted potato both alone and in association with other Fusaria. Wollenweber (1. c. p. 45) stated similarly that F. rubiginosum App. and Wr. (a probable synonym of $F$. culmorum) caused rot of potatoes at higher temperatures, but irregularly. The writer has isolated organisms similar morphologically to $F$. culmorum several times from rotted potatoes. In an endeavor to determine whether the morphological or physiological nature of these fungi might be altered by continued development on a host other than their characteristic habitat, inoculations were made with $F$. lini, F. culmorum, and the Fusaria mentioned above as pathogenic to peas and to beans. Some rots of potato tubers were secured with all these forms, particularly with $F$. culmorum (see Figures 23 and 24). As yet these Fusaria have not been noticeably changed in morphology or pathology, but experiments should be continued for a much longer time.

\section{THE PRODUCTION OF “TOXIC SUBSTANCES” BY FUSARIA}

Lutz (35) has tested the effect of used nutrient solutions, including old Fusarium ("F. solani") solutions, upon the germination and development of certain fungi. He found that such fungi produced, after a period of growth upon a medium, substances which retarded the germination or growth of fungi grown subsequently in the same medium, even tho more nutrient substances were added; other fungi produced substances acting as accelerators rather than retarders. 
Sometimes both types of substances were produced by the same fungus. The effect of these substances was usually destroyed by boiling, or even by lower temperatures. He was, however, unsuccessful in certain other attempts to demonstrate an enzymatic nature of these substances. Old Fusarium solutions which had been boiled and exposed to the light, allowed in general a larger growth of the fungus subsequently introduced than did the unheated solutions. He found also that for some of his used solutions, filtration through a clay filter removed the accelerating or retarding substances, altho this filtration did not alter the solutions in other instances. Lutz concludes that "Die von bestimmten Pilzen produzierten wachstumshemmenden resp. fördernden Stoffwechselprodukte, welche durch Kochen zerstört werden, haben keine spezifische Wirkung in dem Sinne dass sie immer nur auf Keimung und Wachstum derselben Pilzspezies Einfluss hätten; sie wirken auch auf die Sporen anderer Pilze."

On Currie's (14) solution the writer grew $F$. oxysporum, $F$. discolor sulphureum, the Fusarium injurious to peas, Rhizopus nigricans, and other fungi. After the fungi grew for different periods of time, these solutions were filtered carefully through filter paper, since a clay filter may, according to Lutz, absorb the products in question. The results of preliminary germination tests made with spores of $F$. oxysporum and $F$. discolor sulphureum, agreed in general with Lutz's results, and indicated that substances were produced by these fungi which were inhibitory to the subsequent germination and early development of the two Fusaria in the same solution. Boiling the solutions destroyed this inhibitory action.

Coons (13) reported work showing that $F$. oxysporum produced substances filterable through a Berkefeld filter, which caused early wilting of cuttings from potato vines when immersed in the filtered solution. Lathrop (31) found aldehydes to be produced by $F$. cubense E. F. Sm. Peltier (45) determined that a Botrytis produced a "harmful substance" that "may be some inorganic acid other than oxalic, or it may be a toxin of some kind, which, however, is not destroyed by heating to 100 degrees C." Graves (19) found that Rhizopus nigricans produced substances that exerted a negatively chemotropic effect upon the fungus greater than the positive chemotropic effect of certain food materials.

The solutions mentioned above, on which the Fusaria and Rhizopus had grown in Erlenmeyer flasks closed with cotton plugs for different lengths of time, were filtered, and leaves of potato, coleus, ragweed, and other plants, all cut off under water, were introduced (Table VI). 
TABLE VI

Efrects of Solutions in Which Fungi Had Grown, on the Wilting of Excised Leaves

\begin{tabular}{|c|c|c|c|c|}
\hline $\begin{array}{l}\text { Fungus which had } \\
\text { grown in the solution }\end{array}$ & $\begin{array}{l}\text { Time of } \\
\text { growth in } \\
\text { solution }\end{array}$ & $\begin{array}{l}\text { Treatment of solution } \\
\text { after filtration }\end{array}$ & $\begin{array}{l}\text { Plant from } \\
\text { which leaves } \\
\text { were taken }\end{array}$ & $\begin{array}{l}\text { Approximate } \\
\text { time before } \\
\text { consp. } \\
\text { wilting }\end{array}$ \\
\hline & & & & Hours \\
\hline F. oxysporum & 2 months & None & Potato & $2 *$ \\
\hline F. oxysporum & 2 months & Boiled & Potato & 2 \\
\hline F. oxysporum & 2 months & Diluted half with water & Potato & 4 \\
\hline F. oxysporum & 2 months & Diluted and boiled & Potato & 4 \\
\hline F. oxysporum & 2 months & None & Coleus & 12 \\
\hline F. oxyeporum & 10 days & None & Potato & $24 \uparrow$ \\
\hline F. oxysporum & 10 days & None & $\begin{array}{l}\text { Lamb's } \\
\text { quarters }\end{array}$ & $4 \dagger$ \\
\hline F. oxysporum & 42 days & None & Potato & 7 \\
\hline F. oxysporum & 42 days & Diluted half with water & Potato & 8 \\
\hline F. oxysporum & 42 days & $\begin{array}{l}\text { Filtered through diatoma- } \\
\text { ceous earth }\end{array}$ & Potato & 10 \\
\hline F, oxysporum & 42 days & None & Ragweed & 7 \\
\hline F. oxysporum & 42 days & Diluted half with water & Ragweed & 7 \\
\hline F. oxysporum & 42 days & $\begin{array}{l}\text { Filtered through diatoma- } \\
\text { ceous earth }\end{array}$ & Ragweed & 8 \\
\hline F. discolor sulphureum & 2 months & None & Potato & 2 \\
\hline F. discolor stulphureum & 2 months & Boiled & Potato & 2 \\
\hline F. discolor sulphureum & 42 days & None & Potato & 7 \\
\hline F. discolor sulphureum & 42 days & Boiled & Potato & 8 \\
\hline F. discolor sulphureum & 42 days & None & Ragweed & 6 \\
\hline F. discolor sulphureum & 42 days & Boiled & Ragweed & 6 \\
\hline Fusarium from pea & 2 months & None & Potato & 3 \\
\hline Fusarium from pea & 2 months & None & Coleus & 12 \\
\hline Fusarium from pea & 2 months & $\begin{array}{l}\text { Diluted half with water and } \\
\text { neutralized }\end{array}$ & Potato & 4 \\
\hline Pusarium from pea & 2 months & Diluted as above and boiled & Potato & 4 \\
\hline Fusarium from pea & 2 months & $\begin{array}{l}\text { Diluted with } 3 \text { vols. water } \\
\text { and neutralized }\end{array}$ & Potato & 4 \\
\hline Fusarium from pea & 2 months & Diluted as above and boiled & Potato & 4 \\
\hline Fusarium from pea & 42 days & None & Potato & 7 \\
\hline Fusarium from pea & 42 days & Made slightly alkaline & Potato & $7 \ddagger$ \\
\hline Fusarium from pea & 42 days & Diluted with 3 vols. water & Potato & 8 \\
\hline Pusarium from pea & 42 days & Boiled & Potato & 7 \\
\hline Fusarium from pea & 42 days & None & Ragweed & 4 \\
\hline Fusarium from pea & 42 days & Made slightly alkaline & Ragweed & 4 \\
\hline Fusarium from pea & 42 days & Diluted with 3 vols. water & Ragweed & 5 \\
\hline Fusarium from pea & 42 days & Boiled & Ragweed & 3 \\
\hline Rhizopus nigricans & 2 months & None & Potato & $11 / 2$ \\
\hline Rhizopus nigricans & 2 months & None & Coleus & 5 \\
\hline Rhizopts nigricans & 42 days & None & Potato & 7 \\
\hline Rhizopus nigricans & 42 days & Boiled & Potato & 6 \\
\hline Rhizopus nigricans & 42 days & Boiled & Ragweed & 6 \\
\hline Rhizopus nigricans & 42 days & None & Ragweed & 6 \\
\hline None & None & Curries, freshly made & Potato & $24+$ \\
\hline None & None & Curries, freshly made, boiled & Potato & $24+$ \\
\hline None & None & Curries, 42 days old & Potato & 16 \\
\hline None & None & Curries, 42 days old & Ragweed & 10 \\
\hline None & None & Curries, 42 days old, boiled & Potato & 14 \\
\hline None & None & Curries, 42 days old, boiled & Ragweed & 10 \\
\hline None & None & Tap or distilled water & Potato & $48+$ \\
\hline None & None & Tap or distilled water & Coleus & $48+$ \\
\hline None & None & Tap or distilled water & Ragweed & $24+$ \\
\hline
\end{tabular}

- Potato leaves for tests at any one time were taken from plants of the same age and in similar condition. For the two-months-old solutions, the leaves were from full-grown potato plants.

$\dagger$ Tests after ten days reported in only this case, since with all the solutions it was evident that no particular development of "toxic substance" had ensued.

$\ddagger$ Wilt less pronounced than in preceding case. 
Tests were also run with other Fusaria, and with Rhizoctonia and Penicillium. Wilting of excised leaves of various plants ensued more rapidly in old solutions. Wilting occurred even after considerable dilution. It is not to be explained on the basis of acidity. It is to be noted that no specific action is evident between the fungi tried and any one plant; potato leaves wilt as readily in old Rhizopus solutions as in solutions in which $F$. oxysporum had grown. This is in agreement with Lutz's results in growing fungi in old solutions. A difference exists, in that boiling the solution exerts no evident effect upon the action of old solutions on the leaves. In certain cases leaves took on a crinkled, distorted, or mosaic appearance, resembling sometimes the condition obtained by Smith $(62, \mathrm{pl} .63)$.

\section{"MIXED CULTURE" RELA'TIONSHIPS}

Nature seldom works with pure cultures. The interrelationships of various organisms forming the mixed cultures of nature have received little study (see Rahn 54, p. 181). In view of the frequency with which various bacteria may be associated with Fusaria in wilt diseases and tuber rots, the writer undertook tests to ascertain some relations between certain bacteria and Fusaria.

It is a matter of common observation that fungi belonging to the genus Fusarium grow vigorously on any of the common culture media. Indeed, Fusaria are often troublesome as saprophytes in isolation, dilution, and other cultures of various organisms, on account of the vigor and rapidity of their growth. The writer has observed Fusaria to grow over and "swamp" colonies of Penicillium and other fungi.

When, for example, two colonies of the same or of different fungi develop in a Petri dish, there is often a mutual cessation of growth at about the point where the colonies meet. Aside from the possible presence of any growth-arresting substance, there may be a lack of food, or possibly some mechanical obstruction of growth from the presence of hyphae, in the case of fungi. With a bacterial and fungous colony, however, the former should offer less mechanical impediment to the growth of the latter.

Rahn (53) and others have shown that bacteria may produce growth-arresting substances, inhibiting more especially the further growth of the same organism. Elliot (16) has emphasized the changes in the mycelial characters of some species of Alternaria due to contact with colonies of certain bacteria. Sherbakoff $(59$, p. 214 f.) found chlamydospores especially abundant when Fusaria grew in the presence of bacteria. 
In the writer's experiments, Petri dishes of potato dextrose agar were used, inoculated at the center with the Fusarium, and midway on the radii with bacteria at the same time, then incubated until the colonies reached each other. In other cases the bacteria were first inoculated in the center and, since the Fusaria usually grow more rapidly than the bacteria, after incubation from one day to three days the Fusaria were inoculated on the radii. F. oxysporum, F. discolor sulphureum, and the Fusaria from the bean and the pea were employed. Bacillus atrosepticus v. Hall, obtained through the courtesy of Dr. Morse, was used, since the blackleg organism is often found in both the stems and the tubers of potatoes. B. carotovorus Jones, certain undetermined species of bacteria isolated from rotted potato tubers and stems, Pseudomonas phaseoli E. F. Sm., and some common saprophytes such as Bacillus subtilis (Ehr.) Cohn and B. prodigiosus (Ehr.) Fleug., were also employed. Figures 25 to 30 , with explanations in the list of plates, show in detail characteristic results. These experiments, which were duplicated several times, showed that in general a colony of bacteria which exerted a retarding influence on one species of Fusarium, exerted a similar influence on the other three species. Here again no specificity of "toxic substance" for any certain species of fungus was noted. Some bacteria exerted no observed influence, some accelerated, and some retarded growth of the fungus. The production of mycelium was sometimes changed in quantity, or the color reaction upon the medium was altered. On the whole the Fusaria were very tolerant to the presence of bacteria. No marked alteration of the mycelium or spores was found as a result of the action of the bacterial colonies on the fungus. While the writer has no reason to doubt the authenticity or vigor of the bacterial cultures used, he has not checked this point. Table VII summarizes the observations.

TABLE VII

EFFect of Bacteria ON Certain Fusaria

\begin{tabular}{|c|c|c|c|c|c|}
\hline & Bacillus atrosepticus & Ps. & $\begin{array}{l}\text { From } \\
\text { rotted } \\
\text { potato } \\
\text { stem }\end{array}$ & $\begin{array}{c}\text { From } \\
\text { rotted } \\
\text { seed } \\
\text { piece }\end{array}$ & B. subtilis \\
\hline F. oxysporum & $\begin{array}{l}\text { Slight alteration of growth; } \\
\text { aerial mycelium marked }\end{array}$ & $\begin{array}{r}\text { Retarded } \\
\text { growth }\end{array}$ & $\begin{array}{r}\text { Retarded } \\
\text { growth }\end{array}$ & $\begin{array}{l}\text { Retarded } \\
\text { growth } \\
\text { medium } \\
\text { colored }\end{array}$ & No change \\
\hline $\begin{array}{l}\text { F. discolor sul- } \\
\text { phureum }\end{array}$ & & $\begin{array}{r}\text { Retarded } \\
\text { growth }\end{array}$ & $\begin{array}{r}\text { Retarded } \\
\text { growth }\end{array}$ & $\begin{array}{l}\text { Marked } \\
\text { retardation }\end{array}$ & No change \\
\hline F. from bean & $\begin{array}{l}\text { Growth somewhat accelerated, } \\
\text { or no change* }\end{array}$ & $\begin{array}{r}\text { Retarded } \\
\text { growth }\end{array}$ & $\begin{array}{r}\text { Retarded } \\
\text { growth }\end{array}$ & Retardation & $\begin{array}{l}\text { Acceleration } \\
\text { or no change }\end{array}$ \\
\hline F. from pea & No effect noted & $\begin{array}{r}\text { Retarded } \\
\text { growth }\end{array}$ & $\begin{array}{r}\text { Retarded } \\
\text { growth }\end{array}$ & & No change \\
\hline
\end{tabular}

- Acceleration of growth did not ensue in every trial. In general, however, the same results were secured in the different tests. 


\section{GENERAL DISCUSSION}

In considering Fusaria and the diseases they induce, we may first consider these fungi as vigorously growing saprophytes. Their longevity in the soil is a matter of prime importance.

Bolley, in 1901 (5), showed that soil became "flax sick" because of an accumulation of $F$. lini; he stated that when once serious in the soil, "It can live from year to year upon the humus of the soil.... The fungus is able to live in the soil for many years without the presence of a flax crop to feed upon." Orton (40), referring to $F$. oxysporum in the San Joaquin Valley, California, stated that the fungus "may be present in nature in some of these alluvial soils" and at any rate soon accumulated sufficiently in the soil to render potato growing unprofitable. Jensen (26) reported the isolation of $F$. oxysporum from soil from the eastern part of the United States.

It is significant that Pratt $(49,50,51,52)$ found $F$. trichothecioides, $F$. radicicola, and apparently also $F$. oxysporum, in virgin western soils. Werkenthin (74) found in Texas "that the virgin soil contained fungi which are known to be parasitic to cultivated plants, e.g., Fusarium Solani (Mart). Sacc., Fusarium oxysporum Schlecht., and Fusarium radicicola Wollenweber." These fungi he considered "true inhabitants of the soil." Taylor (68) found Fusarium spp. to a depth of 24 inches, in Rhode Island. Coons (13) obtained what was apparently $F$. oxysporum from native Michigan soils.

There is evidence, then, that $F$. oxysporum may be present in many soils, and may become of considerable importance as succeeding crops of potatoes are grown; it must increase greatly from its growth in roots and stems of parasitized plants, and especially from its development on the dying potato stems and their débris. Such saprophytic fungi are able to withstand various unfavorable environmental conditions and persist in the soil through the production of microconidia and macroconidia, chlamydospores, or "perennating mycelium." In their growth, some Fusaria at least are able to compete successfully with various bacteria and other organisms with which they come in contact.

While Fusaria are active saprophytes, there can be, on the other hand, no question as to their seriousness as plant parasites; their abundant saprophytic growth only renders their control in some respects more difficult. Despite their semi-parasitic nature, many $F \mathfrak{u}$ saria, such as $F$. oxysporum, exhibit what amounts to a considerable specificity of parasitism to certain crops. $F$. oxysporum, however, can attack any part of the potato plant; stem, stolon, root, tuber, or even leaf. If the fungus is present in abundance, it can cause a com- 
plete rotting off of the stems. It is not surprising, then, that from plants showing atypical symptoms of wilt in the field, $F$. oxysporum should be isolated, especially when the soil and weather conditions are propitious. The Early Ohio variety has been found to be commonly affected, particularly in the Red River Valley. This may be correlated with the fact that the Early Ohio remains through a considerable period in late summer in a condition of slow maturity and lessened vigor.

In regard to the cause of wilting in potato plants into which F. oxysporum has gained entrance, a common explanation is that of mechanical vascular clogging. Link (35) considers the killing of the root system to be as important as this clogging, and Coons (13, p. 302) would add also the systemic poisoning from the production of substances by the fungus. The writer's experiments indicate that the fungus does produce toxic substances, but that various other fungi produce substances equally toxic, the only specificity being in the fact that the other fungi tried are ordinarily unable to gain entrance into the tissues of the plant. It would seem, however, that the three factors mentioned may operate together, with the addition in cases of foot rot of a considerable rotting of the underground portions of the potato plant.

The association of injury to the potato stem from Rhizoctonia or Colletotrichum atromentarium (Berk. \& Br.) T'aub. (67) and of $F$. oxysporum within such stems, and the occasional coincident occurrence of bacteria, Verticillium, or other fungi with $F$. oxy'sporum indicate that Fusarium wilt ensues more readily when the plant is weakened, and that other organisms may follow or aid the Fusarium in causing injury to the potato plant.

Tisdale (70) has shown that the method of infection by $F$. lini is through root hairs, stomata, or epidermis; in resistant flax the plant was enabled to cork out the perhaps weakened hyphae, which could, however, gain preliminary entrance into the plant. He found further that $F$. conglutinans could penetrate the root hairs of flax, as it normally penetrated cabbage, but in flax it did not develop far. F. lini could also probably penetrate the young root hairs of cabbage.

While rots of potato tubers are attainable in the laboratory with various Fusaria, in Minnesota the economically important Fusarium causing rot of tubers is, as far as the writer's evidence goes, $F$. discolor sulphureum. F. oxysporum may injure the tuber somewhat by development at the stem end or considerably in the vascular system, or occasionally by causing a rot; other Fusaria more rarely cause dry rot alone or in association with other organisms. $F$. discolor sulphureum evidently lives over especially in storage houses; the writer 
has observed it in the fall growing luxuriantly, particularly on dirt floors and walls and on débris in potato houses that had held potatoes the previous year.

Infection of the tuber may sometimes apparently enste from contamination with the organism from the field. Once this fungus gains entrance it can develop at ordinary temperatures regardless of the humidity in storage, tho lower humidity obviously lessens the liability of infection. Relatively low temperatures, particularly cold storage, ( 1 to 3 degrees C.) allow but slight progress of the disease.

While $F$. discolor sulphureum ordinarily gains entrance through wounds, it is worthy of note as reported above that it may sometimes evidently infect through lenticels. In this connection it may be noted that Pratt (49) found that $F$. radicicola might infect the tuber through the stem end, lenticel, or eye; Wilcox, Link, and Pool (75) and Pratt (51) found that $F$. trichothecioides, on the other hand, infected only through bruises or other injury. Experiments and observations indicate that tubers become naturally infected with $F$. discolor sulphureum principally through wounds.

Tomato, cucumber, and some other fruits and various vegetables, especially when mature, may be rotted by several Fusaria. Numerous other fungi, such as Penicillium spp., may also rot these plant parts; the action is hardly more than saprophytic growth upon easily available food material. While various fungi such as Penicillium spp., Aspergillus spp., Stysanus stemonitis, Verticillium sp., Alternaria sp., are often found on or in rotted tubers or on healthy tubers, inoculation experiments failed to show any noteworthy ability of these fungi to rot the potato. The normal tuber is not an available source of food for them. Certain Fusaria are also unable to utilize readily the potato tuber as a food supply.

\section{CONTROL MEASURES}

\section{POTATO WILT}

The methods of control ordinarily recommended are clipping the stem ends and rotation of crops. The former method, while of undoubted value in removing some infection as well as the somewhat weaker eyes near the stem end, is not effective in seriously infected soils. Whether or not $F$. oxysporum occurs naturally in Minnesota soils, it is now widely distributed in the potato growing regions. Observational evidence has failed to show that this fungus seriously attacks other crops in the state. It undoubtedly remains in some abundance in Minnesota soils for a considerable time. 
It seems to the writer that the observation that the Fusarium causing potato wilt in Minnesota attacks the plants more especially at the time when blossoming, tuber setting, and hot weather have reduced the vigor of these plants, offers considerable hope in the development of control measures. From this standpoint the tutilization of more vigorous strains of potatoes, rotation of crops, improvement of the seedbed, clean culture, and other factors tending to produce more vigorous plants likewise lessen the liability to attack by $F$. oxysporum.

The writer is uncertain as to the interpretation to place upon the data presented by Manns (36, p. 317-319) and considered as tending to show that the "fungus will average in sick fields as great a percentage in reduction under favorable conditions as under drouth." Manns evidently bases this conclusion on the fact that a three-year rotation plot at the Ohio station yielded in 1909 only 69 bushels per acre, whereas the county averaged 186 bushels per acre. It would seem, however, that throughout that county, in which the wilt had presumably been present previously (1.c., p. 311), it could not have greatly reduced the yield in 1909 despite the supposed higher percentage of seed infection in 1908 (1.c., p. 319; see also yield of spray plot, as noted below). Of course this does not explain the low yield in the rotation plot at the Ohio station in 1909.

The work of Manns with bordeaux mixture is also significant. He found that despite the fact that "the only active factor at work in 1909 in reducing the yield on the area plotted for spraying was the work of the Fusarium blight, which was very prevalent the growth in all sprayed plots continued from one to three weeks longer than in the unsprayed," with an average yield of 170.36 bushels per acre in the unsprayed and 181.72 bushels per acre in the sprayed plots. He adds, "The writer is satisfied that spraying heavily four times during the season does somewhat retard the action of the $\mathrm{Fu}_{\mathrm{u}}$ sarium fungus. Just how the results are brought about can not be satisfactorily explained." It would seem that the explanation may lie in the increased vitality of plants which are sprayed, and which can thus resist the action of the semi-parasitic $F$. oxysporum. Stewart (66) had previously in New York State obtained a yield of 266 bushels per acre from tubers obtained from wilted vines and in which "when cut at the stem end, blackened fibers are seen penetrating the flesh to a considerable distance." This plot was sprayed thoroly eight or nine times with bordeaux mixture. While it is not certain that Stewart was dealing with $F$. oxysporum wilt, the results obtained are comparable to those secured by Manns. 
The writer has obtained as yet only empirical and fragmentary evidence as to the effect of spraying upon the occurrence of wilt in Minnesota. In the northeastern states, where spraying is commonly practiced, wilt is not prevalent. It must not be forgotten, however, that in this region cool weather and other conditions are more favorable to the production of healthy and vigorous plants than in warmer regions.

The results secured in Minnesota by A. G. Tolaas and certain county agents in the use of seed-plot methods, including selection, treatment, rotation, and good cultural conditions, indicate that wilt may be lessened by methods which tend to add vigor to the plants. A. G. Newhall, in 1918, found a case in point: A field in Cass County, a portion of which had received some care, had 15 per cent of wilt, whereas in another portion in which negligence had allowed weeds to develop and the potato plants to become less thrifty, 30 per cent of wilt occurred.

Removal of débris from a field that had grown potatoes would lessen considerably the amount of culture medium for the Fusarium. The consideration involved as to fungi in returning such débris to the field after a period of rotting, is undetermined.

\section{POTATO DRY ROT}

Control measures that may be used against the rot caused by $F$. discolor sulphureum have not been found to be different from those recommended by various writers against other fusarial dry rots. Highly important is more careful handling of potatoes during and after digging to avoid cuts, bruises, and injuries, since the fungus attacks the tubers ordinarily and most easily through wounds. Storage cold enough to prevent absolutely the development of this rot is hardly attainable in any storage facilities possessed by the average grower, except possibly in the use of pits in the field. Considerably less infection would probably result, however, if the storage rooms were thoroly disinfected before potatoes were put in, and cleaned out carefully after the potatoes were removed. A disinfection of the tubers before storage would probably be commercially profitable, at least in the case of seed potatoes.

Control measures against root rots of truck crops are indicated in the rotation of crops and the most favorable growing conditions for the crop. Careful handling and clean cool storage of fruits and vegetables subject to Fusarium rots will reduce the injury.

\section{SUMMARY}

1. Fusarium oxysporum Schl. is the cause of one of the most serious diseases of the potato plant in Minnesota. 
2. This fungus characteristically produces the symptoms known as wilt. It attacks the roots and lower stem of the potato plant, particularly during the blossoming and tuber setting periods, when the weather is likely to be unfavorable to the potato, tho not to the fungus. $F$. oxysporum can moreover attack any part of the potato plant, and under certain conditions, particularly in wet soil, causes darkening and rotting of the stem and other symptoms not typical of wilt. It may rot the seed tuber under field conditions.

3. As a saprophyte, $F$. oxysporum grows vigorously on the affected potato plants, accumulates in considerable abundance in the soil throughout the season, and persists for some time. In the fall it may attack plants which have previously produced a normal crop of tubers.

4. The strains of $F$. oxysporum used were not, under ordinary conditions, sufficiently active parasites to cause infection of younger potato plants from artificial inoculations of the soil or seed tuber. At higher temperatures, symptoms of disease may occur. If the soil is inoculated heavily, rotting of the seed tuber and of the sprout or stem may result.

5. Wilted plants do not necessarily result from planting seed tubers from'affected plants. While such "seed" is less satisfactory than tubers produced under healthy vines, other measures in addition to seed selection or clipping off the stem ends are necessary to avoid wilt.

6. While $F$. oxysporum is largely confined to the potato in Minnesota, its habits are for the most part hemi-parasitic.

7. The danger of serious infection by the wilt Fusarium is lessened by measures tending to add to the. vigor of the plants, particularly during the latter part of the season.

8. Fusarium discolor sulphureum is the common cause of storage dry rot of potato tubers in Minnesota.

9. This fungus gains entrance commonly through wounds, tho the rot may sometimes be induced by applying the fungus to the uninjured surface of the tuber.

10. Tubers from normal potato vines rot as readily as those from "constitutionally degenerate" plants, and as readily as tubers showing frost necrosis. None of the varieties of potatoes tested was found to be resistant to this tuber dry rot.

11. Rot may develop on unsprouted tubers, and under dry conditions. Very slight rot may develop even at temperatures below 2 degrees $\mathrm{C}$. 
12. At temperatures below about 16 degrees C., F. discolor sulphureum produces more abundant aerial mycelium; at temperatures of from 20 to 30 degrees $\mathrm{C}$., a dense pseudopionnotes.

13. The starch grains in the tubers affected with dry rot are not appreciably affected.

14. F. discolor sulphureum does not naturally cause a wilt of potato plants, but infected seed tubers may produce less vigorous sprouts, or even no sprouts.

15. While other Fusaria, such as F. oxysporum and F. culmorum may cause rot of potato tubers, such rots have been found to be of little economic importance in storage.

16. Careful handling of tubers and the maintenance of clean cold storage conditions, are important prophylactic measures against the storage rot caused by $F$. discolor sulphureum.

17. Fusarium root rots of Pisum sativum and of Phaseolus vulgaris are of importance in Minnesota.

18. Ear rots of Zea mays due to Fusaria, probably including $F$. culmorum, are common in the state.

19. Cross-inoculations indicate that wilt or root rot producing Fusaria may exhibit a selective tendency in their more common occurrence on certain species of host plants, altho hemi-parasitic in that their action may be more distinctly influenced by conditions unfavorable to the host.

20. A temperature at which the host develops poorly may allow an active development of the attacking Fusarium.

21. Isolations and cross-inoculations demonstrate that no single species of Fusarium is chiefly responsible for the common storage rots of vegetables and of cucumber and tomato fruits.

22. Fusaria produced substances in old solutions that inhibited the germination of spores of the same or other fungi. After boiling, such old solutions allowed normal germination.

23. Substances detrimental to such plants as potato, coleus, and ragweed, as shown by the wilting of excised leaves when placed in solutions, were also produced by Fusaria and other fungi in cultures. This injurious effect persisted after boiling, neutralization, or some dilution of the solutions. Specific fungi did not produce substances selectively injurious to any one or more plants.

24. Fusaria are, in general, little influenced by bacteria, tho some bacteria may influence the rate of growth of Fusaria.

25. The Fusaria examined could withstand considerable dessication, exposure to low temperatures or to alternate freezing and thawing, and can utilize a wide variety of food substances. Altho important pàrasites, Fusaria are efficient saprophytes. 


\section{BIBLIOGRAPHY}

1. Appel, O. Leaf roll diseases of the potato. Phytopath. 5: 139148. 1915.

2. - and Wollenweber, H. W. Grundlagen einer Monographie der Gattung Fusarium (Link). Arb. Kais. Biol. Anst. Land- und Forstw. 8: 1-207, fig. 1-10, pl. 1-3. 1910.

3. Bartram H. E. Effect of natural low temperature on certain fungi and bacteria. Jour. Agr. Res. 5: 651-655. 1916.

4. Bisby, G. R. A Fusarium disease of garden peas in Minnesota. Abs. in Phytopath. 8: 77. 1918.

5. Bolley, H. L. Flax wilt and flax-sick soil. N. Dak. Agr. Exp. Sta. Bull. 50: 27-58. 1901.

6. Brown, C. E., and Wellington, Richard. Standard potato varieties for Minnesota. Minn. Agr. Ext. Div. Spec. Bull. 5: 1-8. pl. 1-8. 1916.

7. Burkholder, W. H. Some root diseases of the bean. Abs. in Phytopath. 6: 104. 1916. See also Phytopath. 7: 61. 1917.

8. Carpenter, C. W. Some potato tuber rots caused by species of Fusarium. Jour. Agr. Res. 5: 183-209. pl. A, B, and 14 to 19.1915.

9. Wilt diseases and the Verticillium wilt problem. Jour. Agr. Res. 12: 529-546. pl. A and 17 to 27. 1918.

10. - Report of the plant pathologist. Hawaii Agr. Exp. Sta. Rept. 1917: 33-42. 1918.

11. Clinton, G. P. Fungous diseases of the potato. Ill. Agr. Exp. Sta. Bull. 40: 136-140. pl. I. 1895.

12. Coons, G. H. In Report of the botanist. Rept. Mich. Bd. of Agr. 1916:270. 1916.

13. Notes on Michigan plant diseases in 1916. Rept. Mich. Bd. of Agr. 1917: 302, 312. 1917.

14. Currie, J. N. The citric acid fermentation of Aspergillus niger. Jour. Biol. Chem. 31: 15-37. p1. 1. 1917.

15. Edson, H. A., and Shapovalov, M. Potato stem lesions. Jour. Agr. Res. 14:213-220. pl. 24-26. 1918.

15a. Edson, H. A. The effect of frost and decay upon the starch in potatoes. Jour. Ind. Eng. Chem. 10: 725-726. 1918.

16. Elliot, John A. Taxonomic characters of the genera Alternaria and Macrosporium. Am. Jour. Bot. 4: 439-476. pl. 19, 20, 1917. 
17. Fitch, C. L., and Bennett, E. R. The potato industry of Colorado. Colo. Agr. Exp. Sta. Bull. 175: 1-80. pl. 1-23. 1910.

18. Gilman, J. C. Cabbage yellows and the relation of temperature to its occurrence. Ann. Mo. Bot. Gard. 3: 25-84. fig. 1-21. pl. 1, 2. 1916.

19. Graves, A. H. Chemotropic reactions in Rhizopus nigricans. Mem. N. Y. Bot. Gard. 6: 323-331. 1916.

20. Haskell, R. J. Potato wilt and tuber rot caused by Fusarium eumartii. Phytopath. 6: 321-327. fig. 1-3. 1916.

21. Hawkins, L. A. Effect of certain species of Fusarium on the composition of the potato tuber. Jour. Agr. Res. 6: 183-196. 1916.

22. Hoffer, G. N., and Holbert, J. R. Results of corn disease investigations. Science n.s., 47:246, 247. 1918.

23. Hoffer, G. N., Johnson, A. G., and Atanasoff, D. Corn root rot and wheat scab. Jour. Agr. Res. 14:611, 612. 1918.

24. Humphrey, H. B. Studies on the relation of certain species of Fusarium to the tomato blight of the Pacific northwest. Wash. Agr. Exp. Sta. Bull. 115 : 1-22. pl. 1-5. 1914.

25. Jamieson, C. A., and Wollenweber, H. W. An external dry rot of potato tubers caused by Fusarium tricothecioides Wollenw. Jour. Wash. Acad. Sci. 2: 146-152. 1912.

26. Jensen, C. N. Fungous flora of the soil. N. Y. Cornell Agr. Exp. Sta. Bull. 315: 414-501. fig. 100-134. 1912.

27. Jones, L. R. Potato diseases in Wisconsin and their control. Wis. Agr. Exp. Sta. Cir. 36: 1-10. 1912. See also Cir. 52: 1-19. 1914.

28. Soil temperature as a factor in phytopathology. Plant World. 20:229-237. fig. 1, 2. 1917.

29. - and Bailey, Ernest. Frost necrosis of potato tubers. Abs. in Phytopath. 7:71, 72. 1917.

30. Kohler, A. R. Potato experiments and studies at University Farm. Minn. Agr. Exp. Sta. Bull. 114: 287-333. 1909.

31. Lathrop, E. C. The generation of aldehydes by Fusarium cubense. Phytopath. 7: 14-16. 1917.

32. Lewis, C. E. Comparative studies of certain disease-producing species of Fusarium. Me. Agr. Exp. Sta. Bull. 219: 203-258. fig. 86-118. 1913.

33. Link, G. K. K. A physiological study of two strains of Fusarium in their causal relation to tuber rot and wilt of potato. Bot. Gaz. 62: 169-209. fig. 1-13. 1916. Also Neb. Agr. Exp. Sta.

Res. Bull. 9: 1-45. 1916. 
34. Link, H. F. Observationes in Ordines Plantarum naturales. Dissertatio I. Magaz. Ges. Naturf. Freunde. Berlin. III. p. 3-42. 1809.

35. Lutz, C. Ueber den Einfluss gebrauchter Nährlösungen auf Keimung und Entwicklung einiger Schinmelpilze. Ann. Myc. 7: 91-133. 1909.

36. Manns, T. F. The Fusarium blight (wilt) and dry rot of the potato. Ohio Agr. Exp. Sta. Bull. 229: 299-337. pl. 1-15. 1911.

37. Milbrath, D. G. Potato diseases in North Dakota. N. Dak. Farmers Inst. Monthly 14: 81-95. fig. 1-8. 1914.

38. Nicholls, H. M. Plant diseases in Tasmania. Agr. and Stock Dep. Tasmania Rep. 1915-16: 18-20. 1916. Original not seen; abs. in Exp. Sta. Rec. 36: 846. 1917.

39. Orton, C. R. The diseases of the potato. Pa. Agr. Exp. Sta. Bull. 140: 1-37. fig. 1-23. 1916.

40. Orton, W. A. Potato diseases in San Joaquin County, California. U. S. Dept. of Agr. B. P. I. Cir. 23: 1-14. 1909.

41. - Powdery dry-rot of the potato. U. S. Dept. Agr. B. P. I. Cir. 110: 13-15. 1913.

42. Potato wilt, leaf-roll, and related diseases. U. S. Dept. of Agr. B. P. I. Bull. 64: 1-48. pl. 1-16. 1914.

43._ and Link, G. K. K. Powdery dry rot of potato (Fusarium). U. S. Dept. of Agr. Cotton, truck and forage crop diseases, Cir. 1: 1-4. fig. 1. 1918.

44. Pammel, L. H., King, C. M., and Seal, J. L. Studies on a Fusarium disease of corn and sorghum. Iowa Agr. Exp. Sta. Res. Bull. 33: 115-136. fig. 1-15. 1916.

45. Peltier, G. L. A consideration of the physiology and life history of a parasitic Botrytis on pepper and lettuce. Ann. Rept. Mo. Bot. Gard. 23: 41-74. pl. 1-5. 1912.

46. Pethybridge, G. H. Dry rot of potato tuber. Econ. Proc. Roy. Dublin Soc. 1: 547-558. pl. 1-48. 1908.

47. - Investigations on potato diseases. Sixth Rept. Dept. Agr. and Tech. Instr. Ireland, Jour. 15: 491-526. 1915.

48. - Investigations of potato diseases. Eighth Rept. Dept. Agr. and Tech. Instr. Ireland, Jour. 17: 595. 1917.

49. Pratt, O. A. A western field rot of the Irish potato tuber caused by Fusarium radicicola. Jour. Agr. Res. 6: 297-309. pl. 34-37. 1916.

50. - Experiments with clean seed potatoes on new land in southern Idaho. Jour. Agr. Res. 6: 573-575. 1916. 
51. Control of the powdery dry rot of potatoes caused by Fusarium trichothecioides. Jour. Agr. Res. 6: 817-832. pl. 108. 1916.

52. - Soil fungi in relation to diseases of the Irish potato in southern Idaho. Jour. Agr. Res. 13: 73-100. pl. A and B. fig. 1-4. 1918.

53. Rahn, O. Ueber den Einfluss der Stoffwechselprodukte auf das Wachstum der Bakterien. Cent. Bakt. II Abt. 16: 417-429. 609-617. 1908.

54. —_ In Marshall, Microbiology : 81-184. P. Blakiston's Son \& Co. Philadelphia. 1911.

55. Reddick, D. Effect of soil temperature on growth of bean plants and upon their susceptibility to a root parasite. Am. Jour. Bot. 4: 513-519. 1917.

56. Shapovalov, M. Intoxicating bread. [Review of papers of Naumov, N. A., and Pomasski, A.] Phytopath. 7: 384-386. 1917.

57. Shear, W. V. Potato growing in the San Joaquin and Sacramento deltas of California. Cal. Agr. Exp. Sta. Cir. 120: 1-17. fig. 1-7. 1914.

58. Sheldon, J. L. A corn mold. Neb. Agr. Exp. Sta. Rept. 17: 23-32. 1904.

59. Sherbakoff, C. D. Fusaria of potatoes. N. Y. Cornell Univ. Agr. Exp. Sta. Memoir 6: 87-270. fig. 1-51. pl. 1-7. 1915.

60. Shikorra, G. Fusarium-Krankheiten der Leguminosen. In Appel, Beitrage zur Kenntnis der Fusarien und der von ihnen hervorgerufenen Pflanzenkrankheiten. Arb. Kais. Biol. Anst. Land. Forstwirtsch. 5:157-188. 1906.

61. Smith, E. F. Wilt disease of cotton, watermelon, and cowpea. U. S. Dept. Agr. Div. Veg. Phys. and Path. 17: 1-72. pl. 1-10. 1899.

62. Mechanism of tumor growth in crowngall. Jour. Agr. Res. 8: 165-186. pl. 4-65. 1917.

63. and Swingle, D.B. The dry rot of potatoes due to Fusarium oxysporum. U. S. Dept. Agr. B.P.I. Bull. 55: $1-64$. pl. 1-8. 1904.

64. Stakman, E. C., and Tolaas, A. G. Potato diseases. Minn. Agr. Ext. Bull. 35 : 1-15. fig. 1-7. 1912.

65. Stewart, F. C. Another stem-blight of potatoes. N. Y. Geneva Agr. Exp. Sta. Bull. 101 : 83-84. 1895.

66. The communicability of potato stem-blight. N. Y. Geneva Agr. Exp. Sta. Bull. 138: 632-634. 1898. 
67. Taubenhaus, J. J. A contribution to our knowledge of silver scurf (Spondylocladium atrovirens Harz.) of the white potato. Mem. N. Y. Bot. Gard. 6: 549-560. pl. 41-43. 1916.

68. Taylor, Minnie W. Preliminary report of the vertical distribution of Fusarium in soil. Phytopath. 7: 374-378. 1917.

69. Tisdale, W. H. Relation of temperature to the growth and infecting power of Fusarium lini. Phytopath. 7:356-360. fig. 1. pl. 11. 1917.

70. Flax wilt: A study of the nature and inheritance of wilt resistance. Jour. Agr. Res. 11: 573-606. fig. 1-8. pl. 44-46. 1917.

71. U. S. Dept. of Agr. B. P. I. Plant Disease Survey. Plant Disease Bull. 1 Nos. 1-7: 1-131. 1917.

72. - 2:1-226. 1918.

73. Van Hall, C. J. J. Die Sankt-Johanniskrankheit der Erbsen, verursacht von Fusarium rasinfectum Atk. Ber. Deutsch. Bot. Gesells. 21: 2-5. 1903.

74. Werkenthin, F. C. Fungous flora of Texas soils. Phytopath. 6: 241-253. 1916.

75. Wilcox, E. M., Link, G. K. K., and Pool, V. W. A dry rot of the Irish potato tuber. Neb. Agr. Exp. Sta. Res. Bull. 1: 1-88. fig. 1-15. pl. 1-28. 1913.

76. Wollenweber, H. W. Studies on the Fusarium problem. Phytopath. 3: 24-50. fig. 1. pl. 5. 1913. 


\section{EXPLANATION OF PLATES}

Figure 1. Plant showing typical wilting. Illustration by the courtesy of H. A. Edson of the United States Department of Agriculture. Taken in a field in Clay County, Minnesota, August 11, 1917.

Figure 2. Rather early stage of wilting. Taken by Dr. Edson, also in Clay County, August 11, 1917.

Figure 3. Plants collected August 23, 1918, from Clay County, illustrating the browning and rotting of the lower stems and of the roots. One plant also injured by stalk borer. Isolations yielded Fusarium oxysporum from these and similar plants.

Figure 4. Plants showing similar and serious injury from foot rot, collected August 22 and 23, 1918, from Polk and Clay counties. The large plant illustrates also the external production of fungus after having bèen in a damp place about two days.

Figure 5. Tubers from plants showing foot rot, collected in Polk County, August 22, 1918. F. oxysporum and secondary fungi and bacteria present, causing a rather soft rot of the tubers. This rot was not ordinarily foul smelling. The blackening shows some tendency to follow the fibro-vasctilar bundles.

Figure 6. Seed piece inoculated with $F$. oxysporum, received February 8, 1915, from W. A. Orton. (No. 3394 from Wollenweber's laboratory.) Inoculation September, 1917. The seed piece had rotted, the fungus was present in the stem. Reisolations yielded $F$. oxysporum.

Figure 7. Cage heated by carbon electric lamps to secure higher temperature.

Figure 8. Results of rather heavy inoculation of sterilized soil with $F$. oxysporum in the warmed cage. Seed piece rotted, one stem rotted off, other injured at the base. March, 1918.

Figure 9. A case similar to Figure 8. Stems rotted off or seriously injured at the base. March, 1918.

Figure 10: On the left, plant growing in the warm chamber in sterilized soil infected with F. oxysporum. Moist conditions did not allow a serious wilting, but the plant is affected, particularly as indicated by the upper leaves. On the right, check grown from the same seed in sterilized soil. February, 1918.

Figure 11. Affected plant growing in artificially infected soil. The lower leaves have fallen and the plant is-unthrifty. February, 1918.

Figure 12. Surface view of tubers affected with $F$. discolor sulphureum from Beardsley. The wounds from which infection occurred can be seen on the surface. January, 1918.

Figure 13. Longitudinal sections of the tubers shown in Figure 12. The rotted tissue is dark brown or blackish, containing some "pockets" filled with mycelium and sporodochia of the fungus.

Figure 14. Stem and eye end infection of tubers from Clay County and characteristic of the rather early stage of a considerable infection in that region. Received December 10, 1917. 
Figure 15. Effect of injury, moisture, and temperature on the development of rot by $F$. discolor sulphureum. Figures $A$ to $E$, inclusive, no injury to the surface; inoculum applied to the uninjured epidermis. Figures $F, G$, and $H$, slight injury to the surface before inoculation. Figures $I$ to $L$, considerable wounding of surface previous to inoculation. Figures $A$ and $B$, room temperature, damp. Figures $\mathrm{C}$ and $\mathrm{D}$, room temperature, in a dessicator. Figure E, icebox ( 8 to 10 degrees $C$.), damp. Figure $F$, room temperature, damp. Figure G, room temperature, dessicator. Figure $H$, icebox, damp. Figure I, room temperature, damp. Figure J, room temperature, dessicator. Figure $K$, room temperature and room humidity. Figure L, icebox, damp.

Figure 16. Weak plant secured from planting seed partially rotted with $F$. discolor sulphureum. March, 1918.

Figure 17. Healthy plant from seed tuber planted at same time as that of plant shown in Figure 16. Some rot on seed when planted. The rot did not, however, progress much. March, 1918.

Figure 18. At left, base of plant shown in Figure 16, seed rotted; center, base of plant shown in Figure 17, seed healthy at insertion of stem. At right, another plant similar to the one on the left. March, 1918.

Figure 19. Pea seeds rotted and roots and lower stems of young plants affected with Fusarium isolated from pea plants. Greenhouse inoculations, September, 1917.

Figure 20. Four tubers at left show slight rot, with $F$. discolor sulphureum developed at 1.1 to 1.7 degrees $C$. Plugs cut out of potatoes in inoculating. The browned vascular ring in some of these tubers is.due to frost necrosis, which had developed prior to the subjection to cold storage. Previous experiments demonstrated that this slight necrosis had no influence on the rate of rotting. At the right, a tuber almost wholly rotted when placed in cold storage. The rot progressed little at the temperature mentioned. This tuber was cut before being put in cold storage and shows the development of some mycelium on the cut surface. Duration of experiment, 31 days, March 16 to April 16, 1918.

Figure 21. Rot of potatoes from $F$. discolor sulphureum at 8 to 10 degrees C., artificial inoculation, two weeks' development.

Figure 22. F. discolor sulphureum: center of plate, mycelium produced at 8 to 10 degrees $C$. ; area of less abundant mycelium produced at room temperature, containing many small sporodochia not shown clearly; circumference, mycelium produced again at 8 to 10 degrees $C$.

Figure 23. At the right, tuber rot secured at 25 degrees $C$. with $F$. culmorum from wheat; at left, rot by same fungus at room temperature (about 18 to 20 degrees $C$.$) . Time, two weeks.$

Figure 24. Rot started by $F$. lini on potato tuber. Time, two weeks.

Figure 25. $F$. oxysporum inoculated January 25, 1918, in the center. The stained area (dark red in natural color) shows the area occupied by a colony of bacteria obtained originally from a rotted seed piece and as yet unidentified, over which the fungus grew slowly, as indicated by the lines marking dates. Opposite this a colony of Bacillus atrosepticus was present, but exerted no influence on growth or production of color. A colony of Aspergillus at the margin opposite the stained area checked the growth of the Fusarium. View from lower face of Petri dish. 
Figure 26. View from above, showing mycelium of $F$. oxysporum growing over a colony of $B$. subtilis: aerial mycelium marks the margin; no pause in the growth. The radii, etc., on the opposite side are due possibly to shrinkage of the medium.

Figure 27. F. discolor sulphureum retarded by a colony of bacteria (the same species of bacteria mentioned for Figure 25, obtained from a rotted seed tuber). The fungus eventually grew completely over this colony; the conidia and mycelium produced thereon appeared normal microscopically. Opposite, a colony of Bacillus atrosepticus had exerted no influence upon the growth. This figure illustrates the ample macroconidial production at room temperature. View from above.

Figure 28. Fusarium from bean plant. The irregular bacterial colony, checking growth somewhat, is Pseudomonas phaseoli. (The fungus finally grew entirely over this colony, but more slowly.) Opposite roundish colony is $B$. subtilis. The growth of the colony was noticeably accelerated when this colony was reached, just as the growth has been accelerated on the lower side, where the fungus has pushed out over a colony of $B$. atrosepticus. "Growth arresting and accelerating" substances are evidently produced. The organisms shown in Figures 25 to 28 grew on potato dextrose agar under a bell jar at room temperature. Inoculations January 25, 1918, photographs February 5, 1918.

Figure 29. At right, relation between bacteria from a soft-rotted potato and (1) F. oxysporum, (2) F. discolor sulphureum, (3) Fusarium from pea, (4) Fusarium from bean. Bacteria inoculated in center November 9, 1918, fungi inoculations November 12, photograph November 15. The growth of the fungi was somewhat retarded, and the bacteria tended to grow between the fungous colonies. At left, $B$. atrosepticus in center. Fusaria numbered as at right, inoculations and photographs same date.

Figure 30. At right, $B$. subtilis in center, exerting little influence on the Fusaria. At left, a colony of bacteria isolated from a potato stem has diffused substances through the medium checking equally the growth of the four Fusaria. Reciprocally, the bacterial colony ceased to enlarge. Inoculations in both plates: bacteria, November 9, 1918. Fusaria, November 14, photograph November 25. 


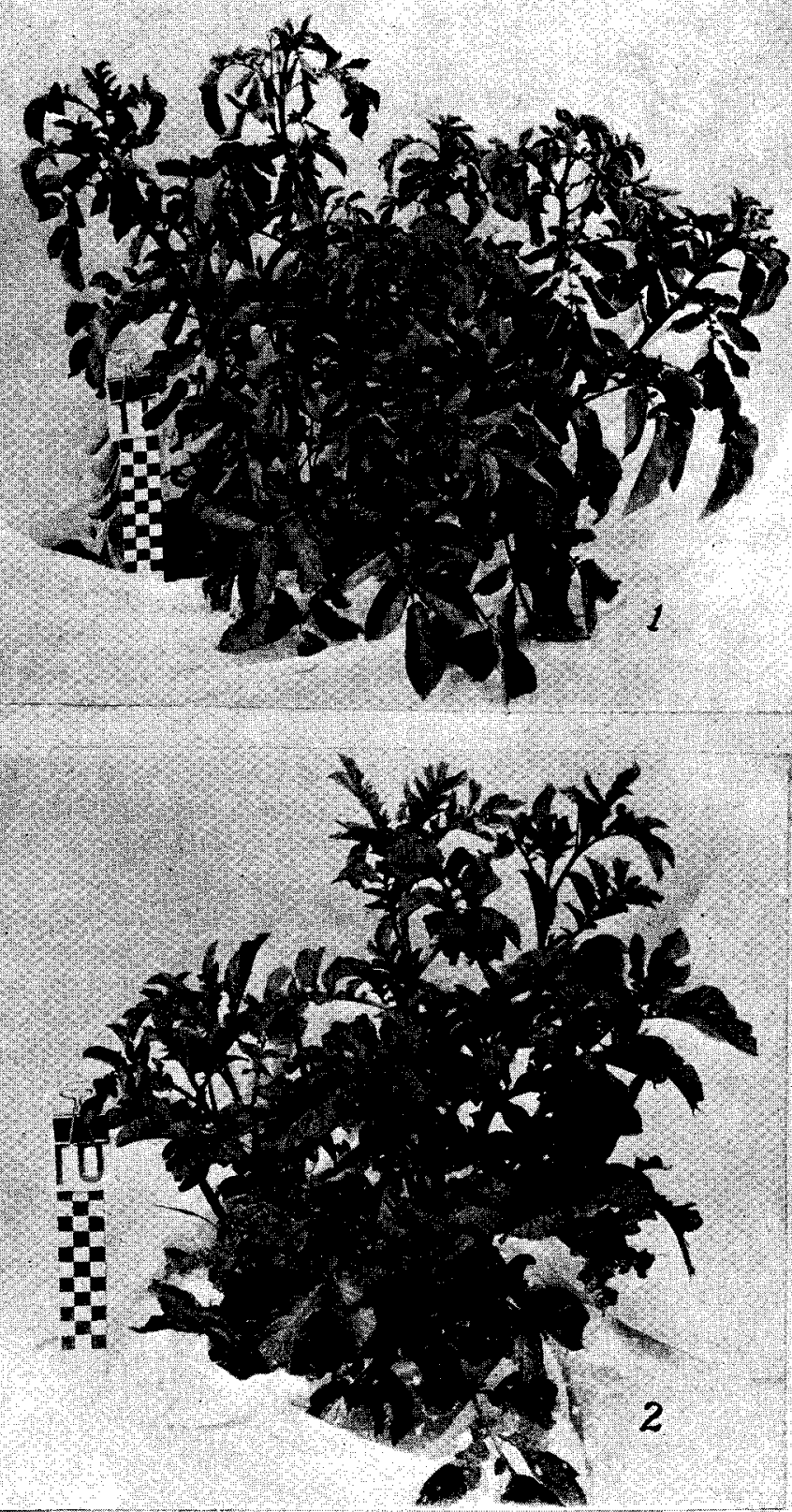



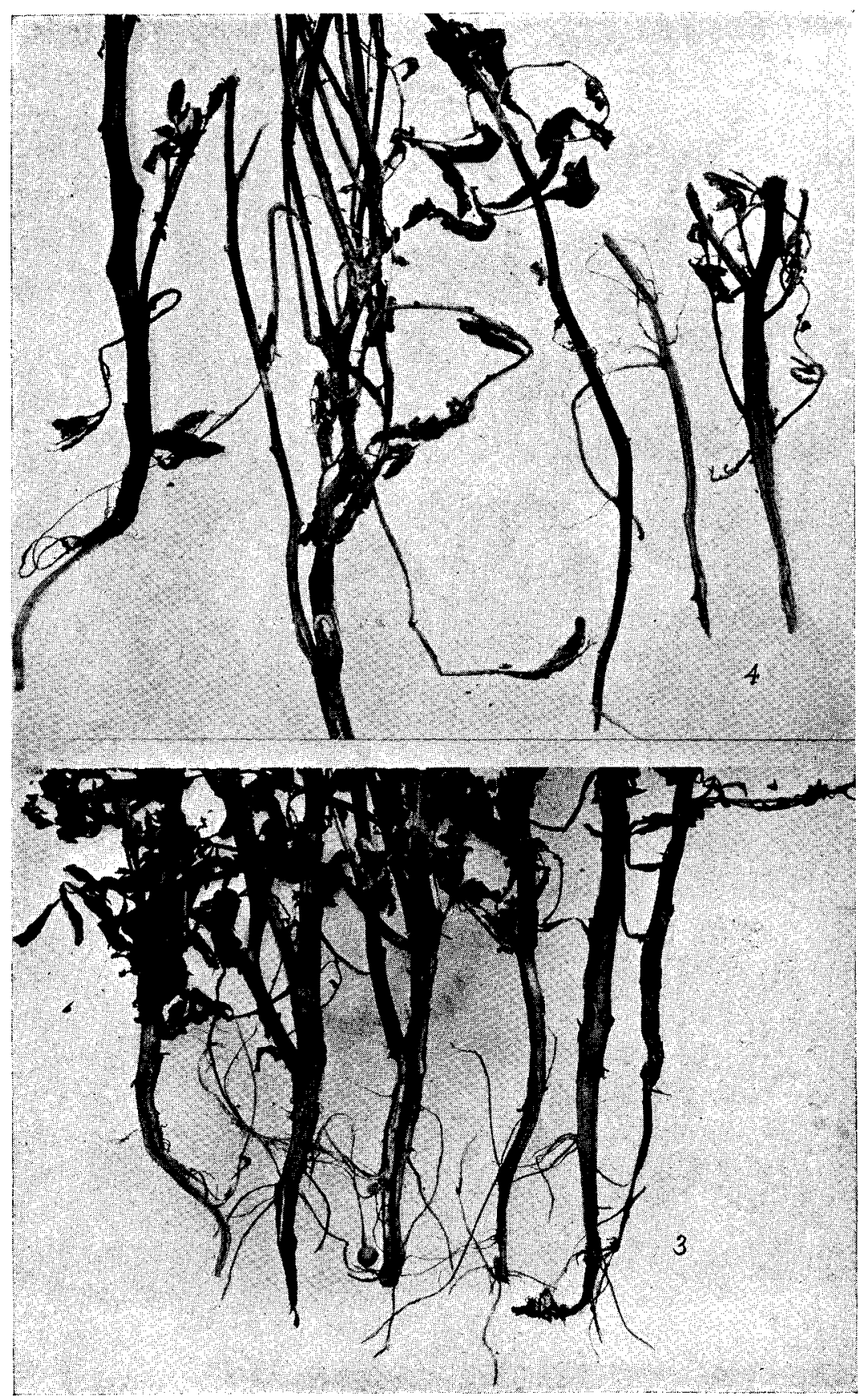


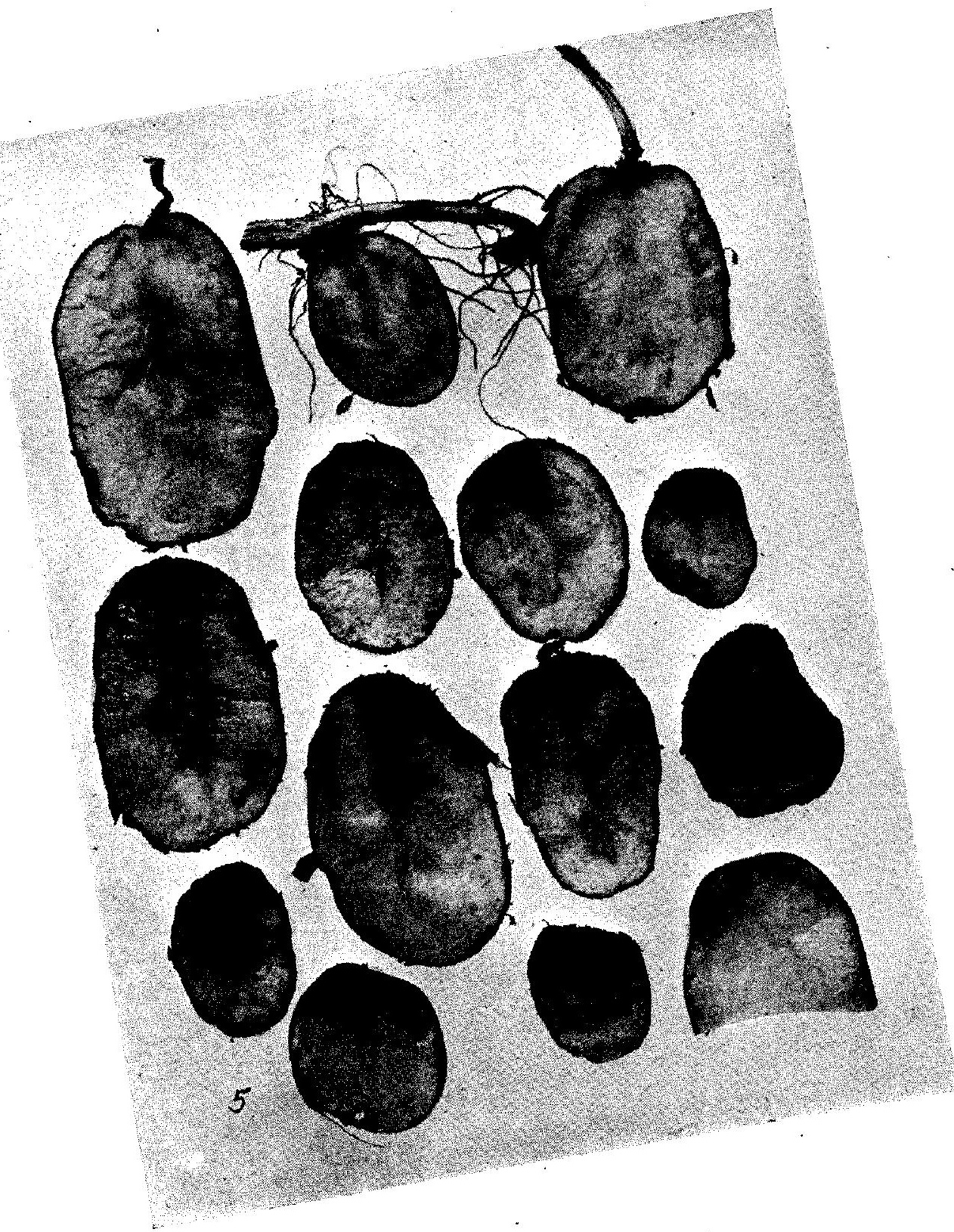



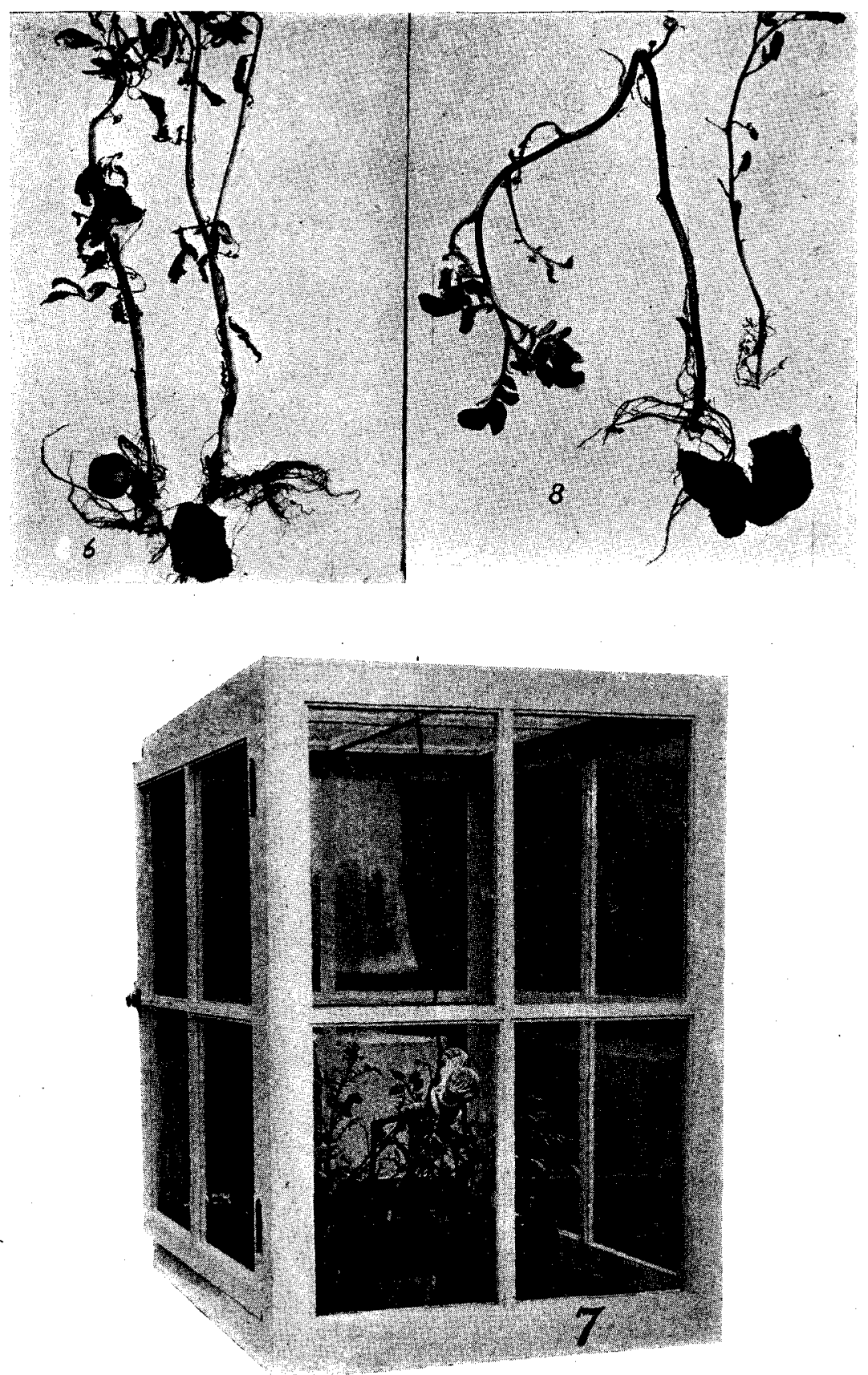


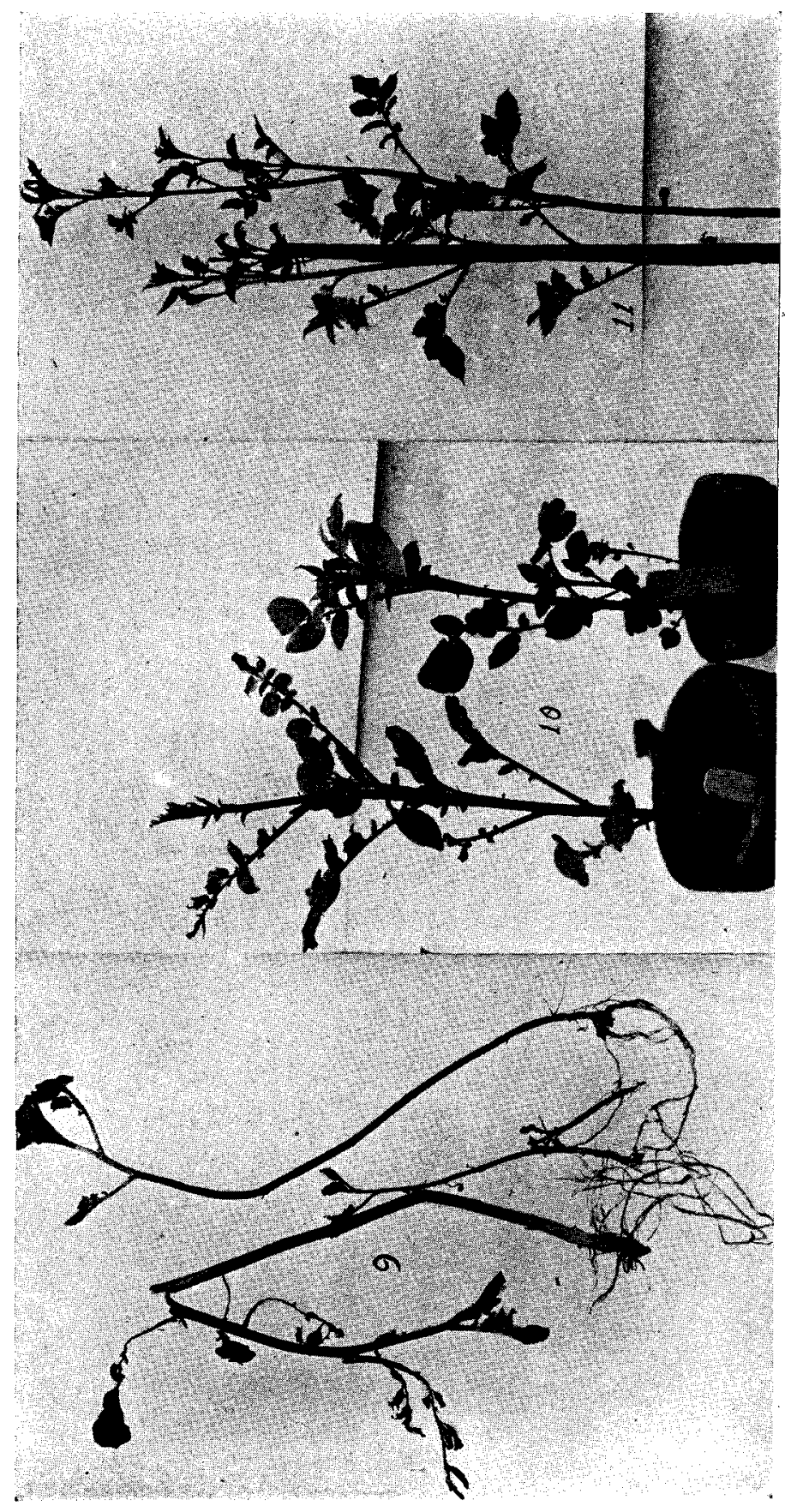




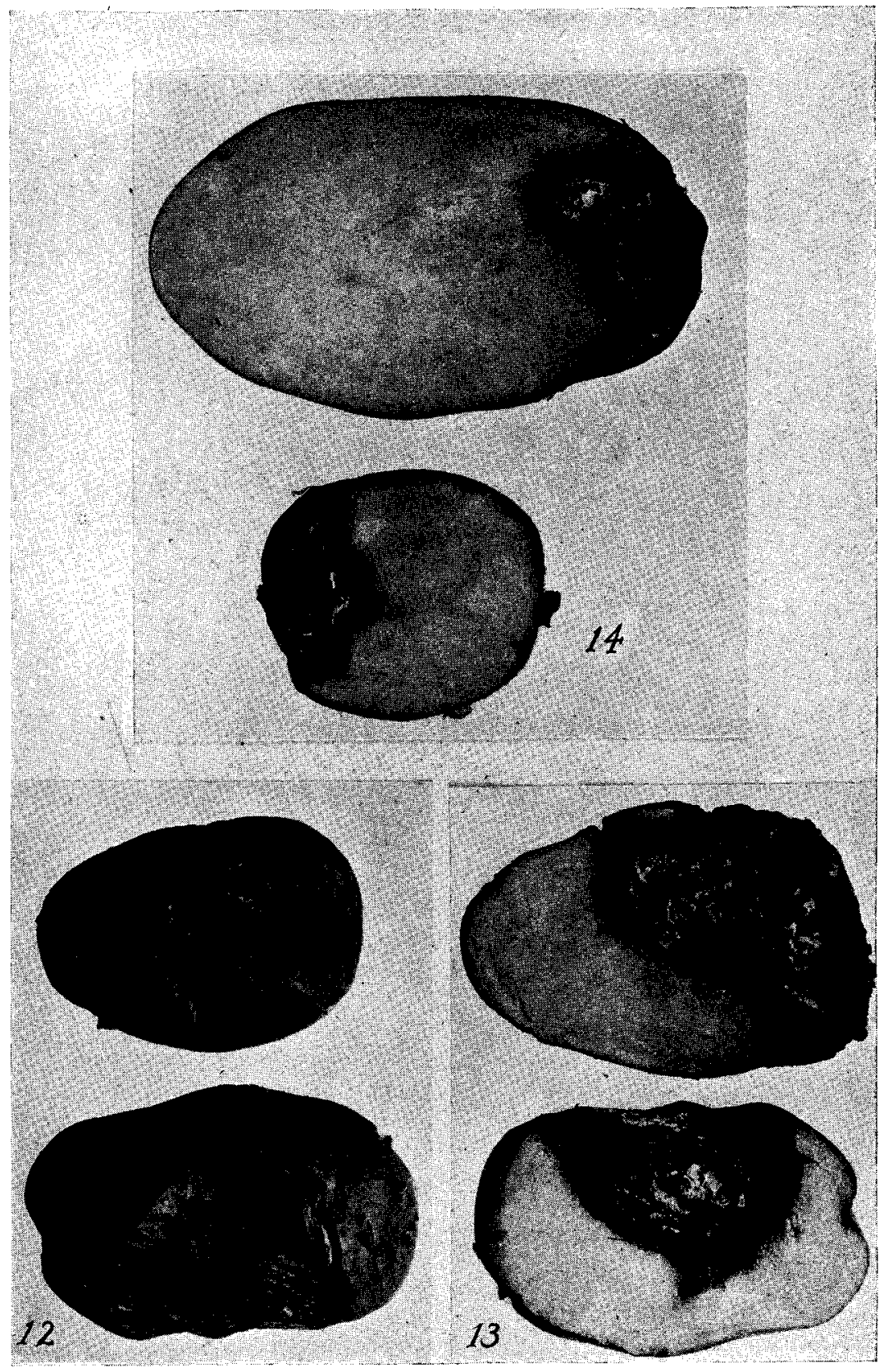



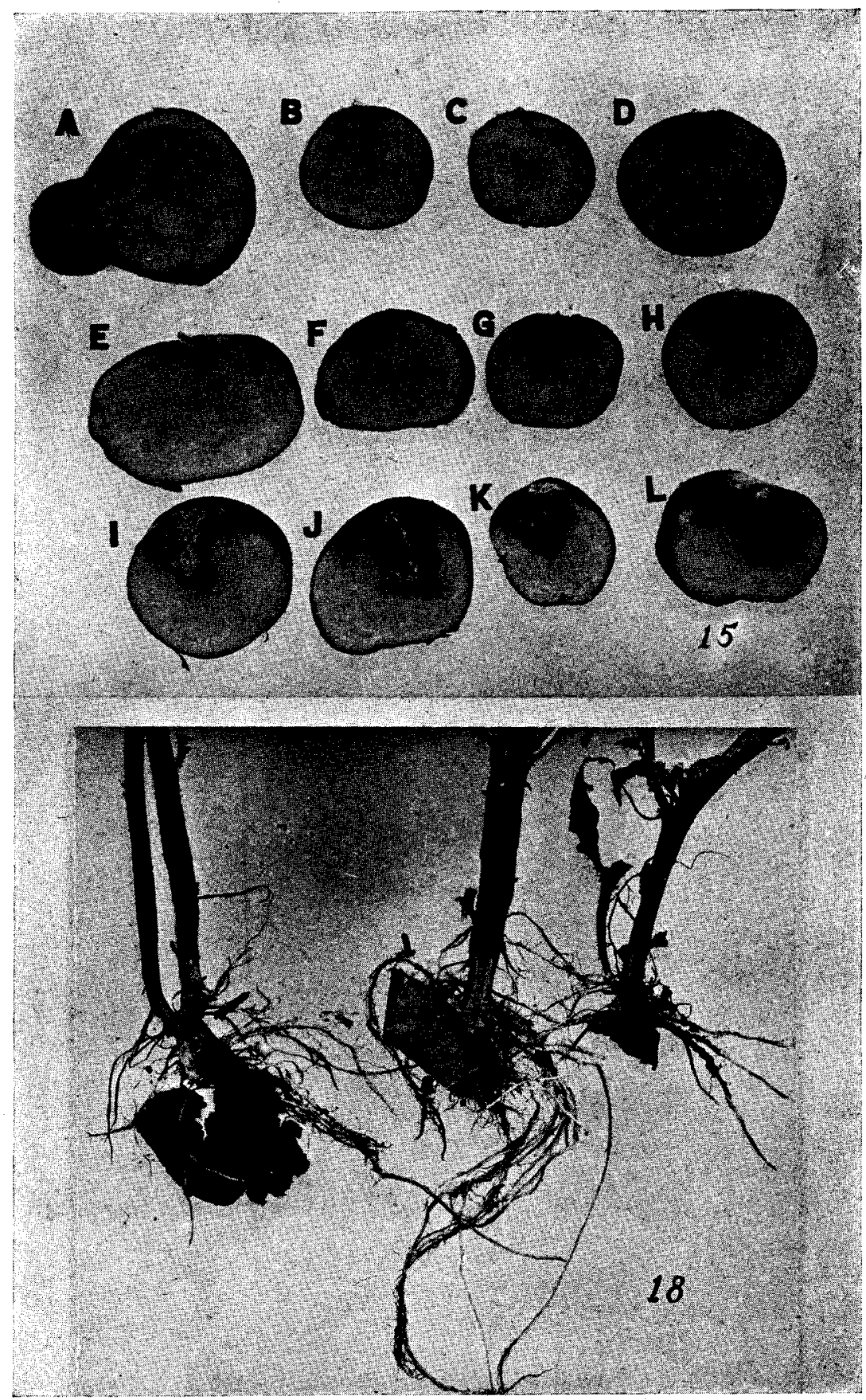


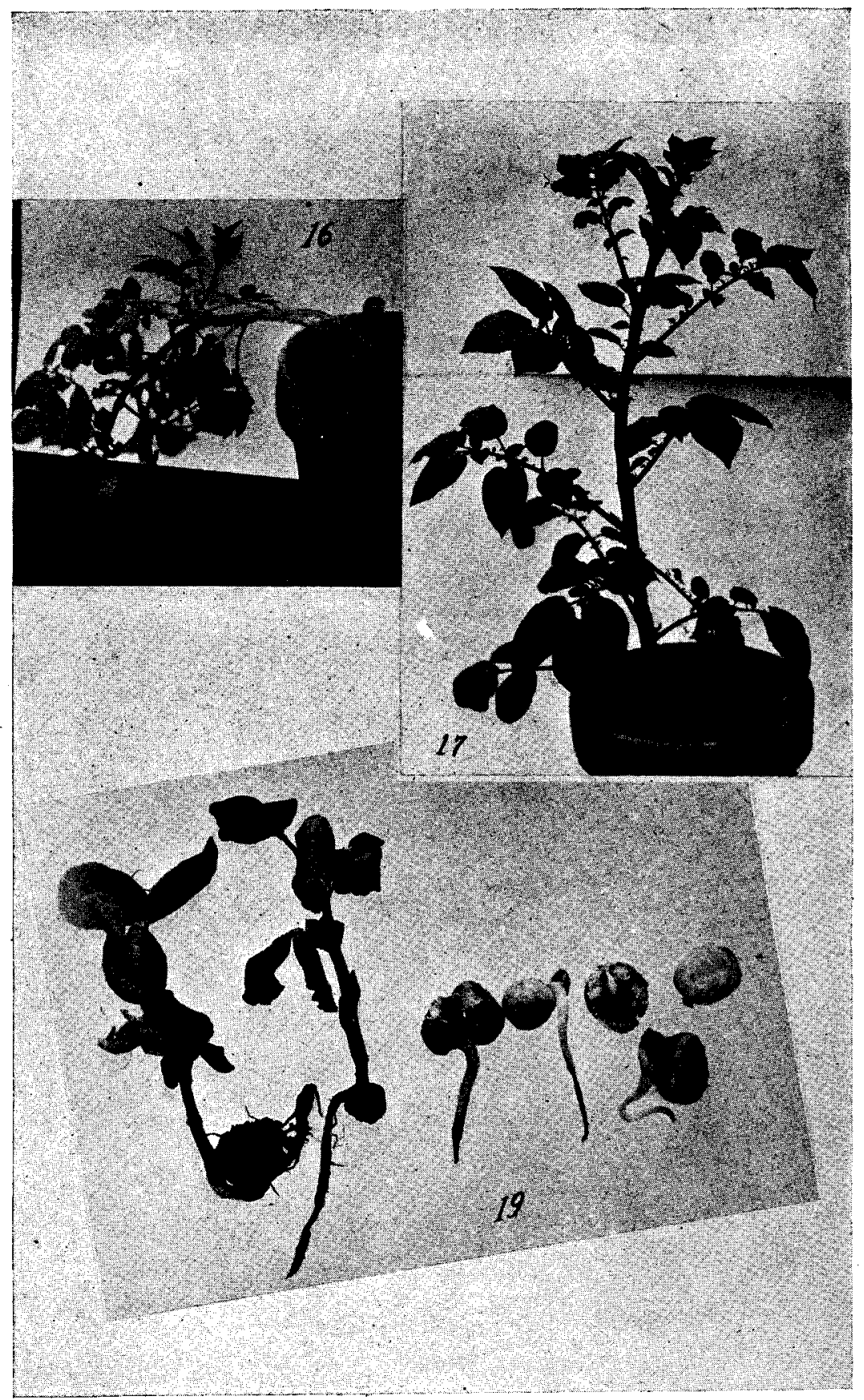




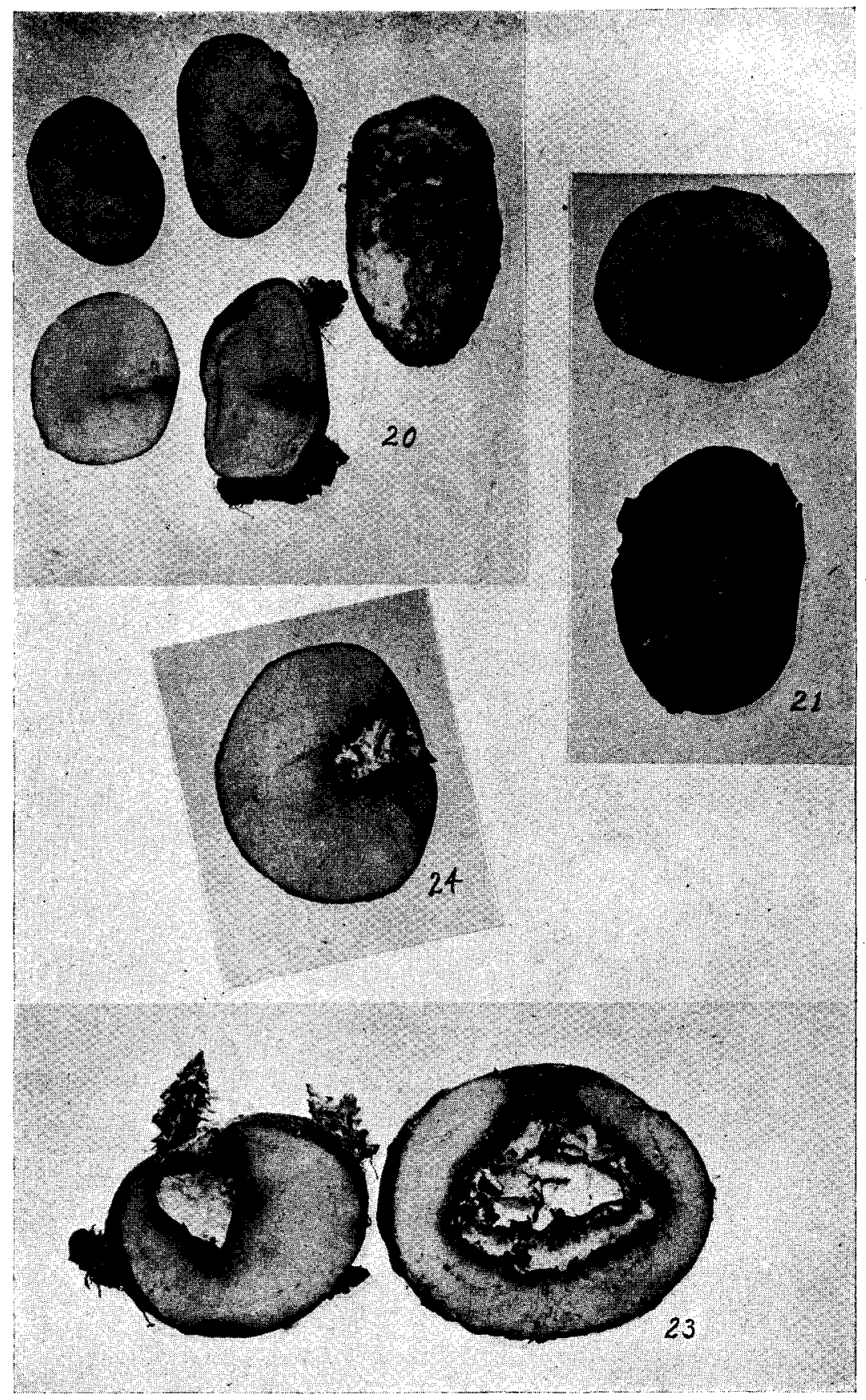




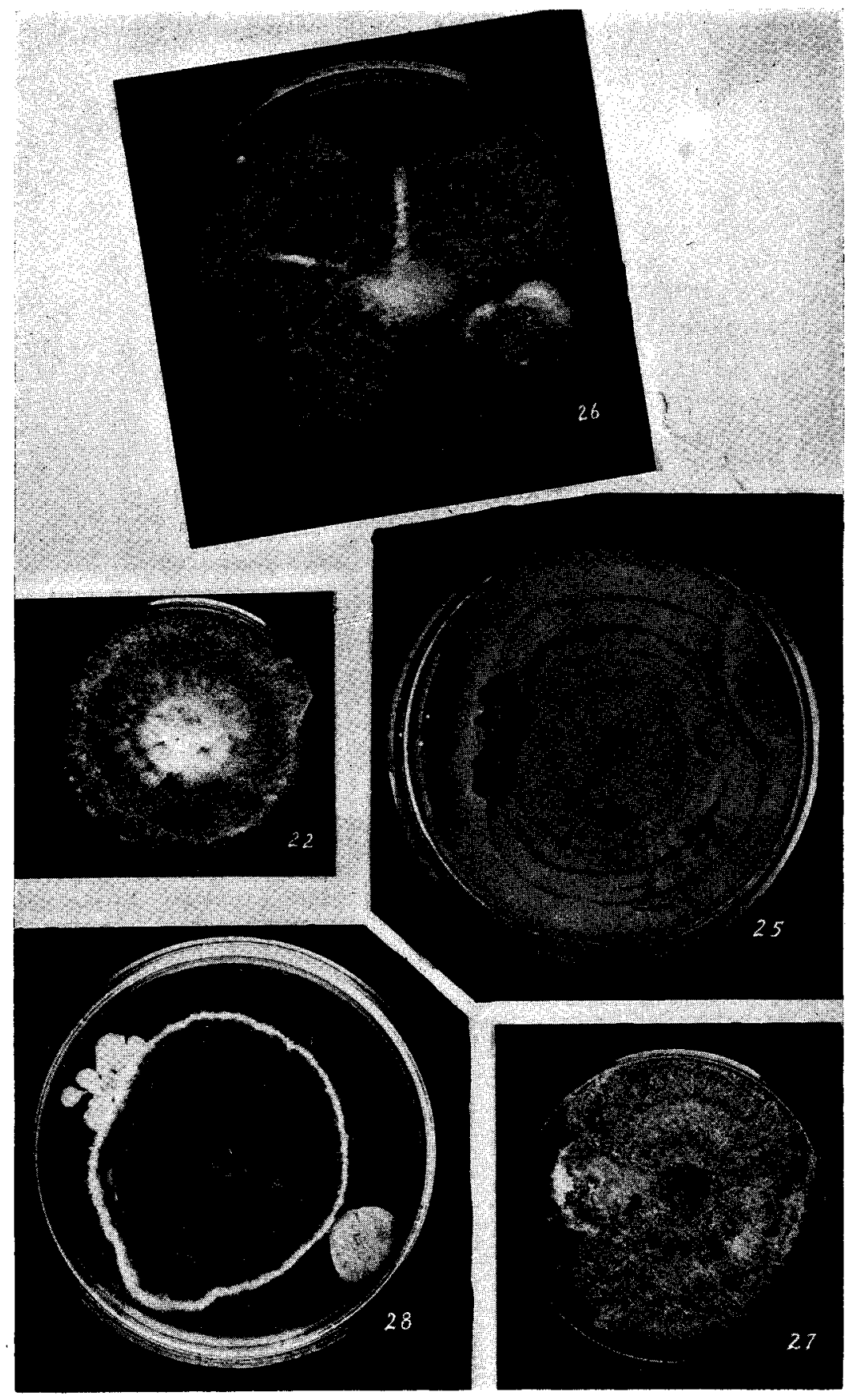



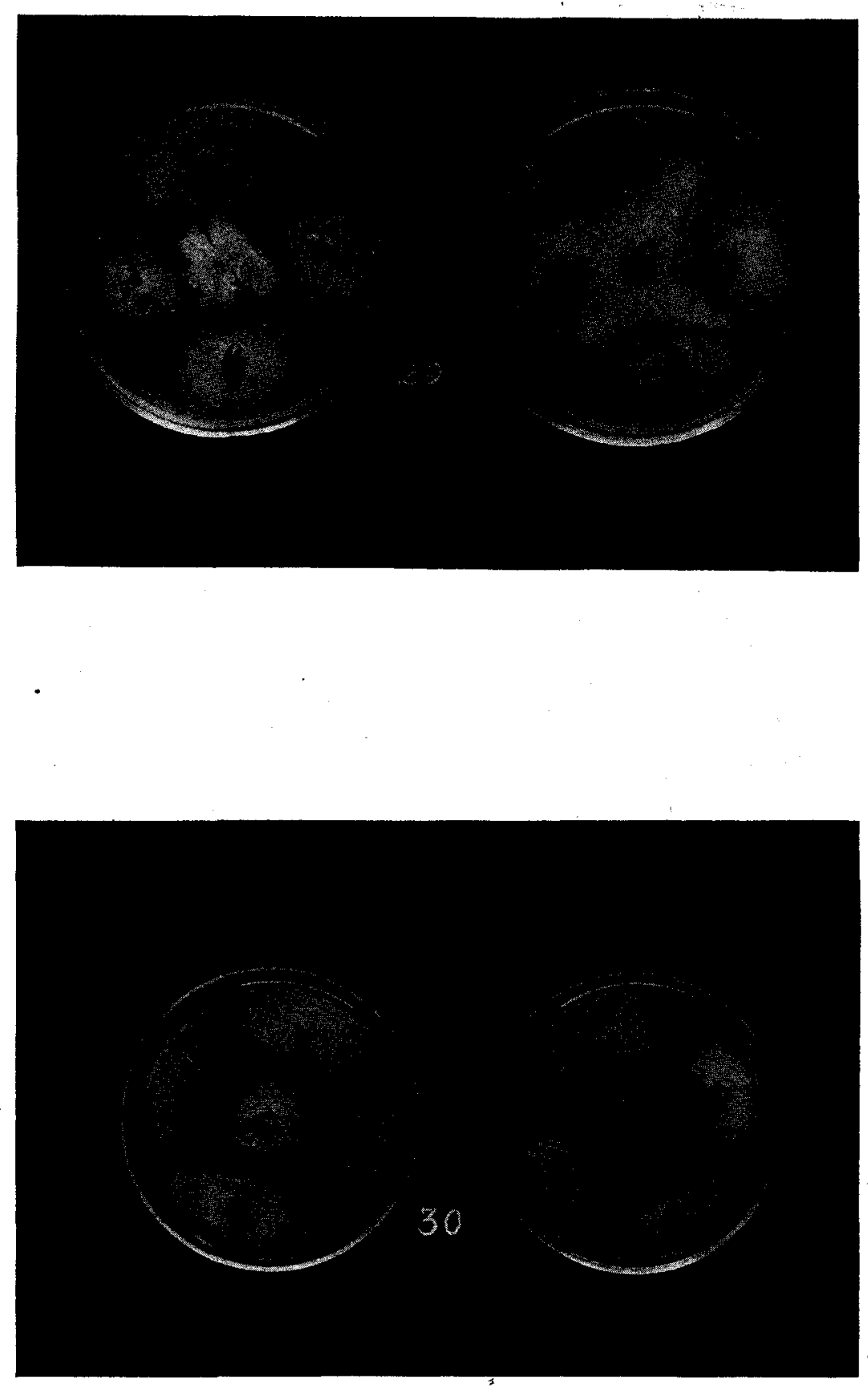